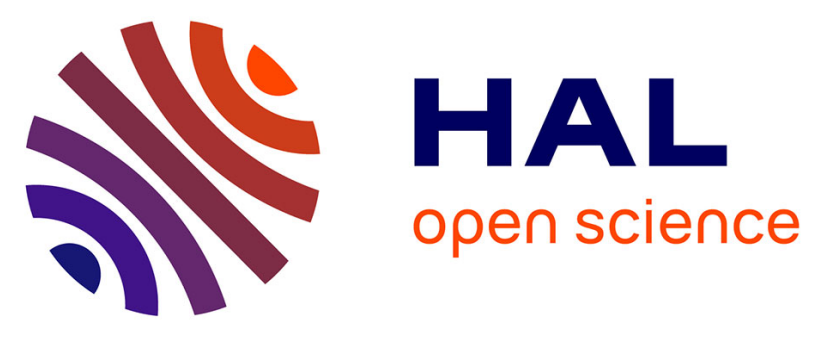

\title{
The adaptive governance of natural disaster systems: Insights from the 2010 mount Merapi eruption in Indonesia
}

Darine Bakkour, Geoffroy Enjolras, Jean-Claude Thouret, Robert Kast, Meif Estuning Tyas Wulan, Budi Prihatminingtyas

\section{To cite this version:}

Darine Bakkour, Geoffroy Enjolras, Jean-Claude Thouret, Robert Kast, Meif Estuning Tyas Wulan, et al.. The adaptive governance of natural disaster systems: Insights from the 2010 mount Merapi eruption in Indonesia. International Journal of Disaster Risk Reduction, 2015, 13, pp.167-188. 10.1016/j.ijdrr.2015.05.006 . hal-01172324

\author{
HAL Id: hal-01172324 \\ https://hal.science/hal-01172324
}

Submitted on 18 Nov 2021

HAL is a multi-disciplinary open access archive for the deposit and dissemination of scientific research documents, whether they are published or not. The documents may come from teaching and research institutions in France or abroad, or from public or private research centers.
L'archive ouverte pluridisciplinaire $\mathbf{H A L}$, est destinée au dépôt et à la diffusion de documents scientifiques de niveau recherche, publiés ou non, émanant des établissements d'enseignement et de recherche français ou étrangers, des laboratoires publics ou privés.

\section{(ㅇ)(1) $\$$}

Distributed under a Creative Commons Attribution - NonCommerciall 4.0 International 
The adaptive governance of natural disaster systems:

Insights from the 2010 Mount Merapi eruption in Indonesia

Darine Bakkour* ${ }^{1}$, Geoffroy Enjolras ${ }^{2}$, Jean-Claude Thouret ${ }^{3}$, Robert Kast ${ }^{4}$, Estuning Tyas Wulan $\mathrm{Mei}^{5}$, Budi Prihatminingtyas ${ }^{6}$

* Corresponding author. Tel. +3306 11740861

66 Bis rue Marcel Miquel, 92130 Issy Les Moulineaux

E-mail address: darinebakkour@hotmail.com

${ }^{1}$ University of Montpellier 1, UMR5474 LAMETA, 34000 Montpellier, France

${ }^{2}$ University of Grenoble Alpes, UMR 5820 CERAG, IAE

Domaine universitaire, B.P. 47, 38040 Grenoble, Cedex 9, France

geoffroy.enjolras@iae-grenoble.fr

${ }^{3}$ University of Clermont, University of Blaise Pascal, Laboratoire Magmas et Volcans, CNRS UMR6524, IRD UR163 and OPGC, 5 rue Kessler, 63038 Clermont-Ferrand, France

J.C.Thouret@opgc.univ-bpclermont.fr

${ }^{4}$ CNRS, UMR5474 LAMETA, SupAgro, 2 Place Viala, 34060 Montpellier Cedex 2, France

IDEP, 2 rue de la vieille Charité, 13002 Marseille, France

kast@supagro.inra.fr

${ }^{5}$ University of Gadjah Mada, Faculty of Geography

Bulaksumur, Yogyakarta 55281

estu.mei@geo.ugm.ac.id

${ }^{6}$ University of Tribhuwana Tunggadewi, Malang, Indonesia

hatmining@yahoo.co.id

Abstract

An adaptive governance system strives to enhance the capacity of institutions to better coordinate relief operations, public awareness and risk reduction policy in case of natural or man-made disasters, by promoting learning from experience. The contribution of this article is twofold: (1) to establish an assessment framework for the adaptive capacity of a system in the field of disasters, and (2) to explore the governance system of Mt. Merapi volcano, Indonesia. We chose the Merapi volcano in the wake of the large 2010 eruption, the largest event over the past 140 years. We develop and apply an assessment framework for the adaptive capacity of a system with the 
following six key parameters: (1) system description, (2) technology, (3) infrastructure, (4) institutions, (5) information and skills, and (6) economic and financial resources. The methodology consists of a qualitative analysis, using a text analysis. The data have been collected from a field survey, which was conducted after the 2010 volcanic eruption and rain-triggered lahars on Mt. Merapi in central Java. We underline a number of challenges, such as apparent lack of appropriate infrastructures, complex interactions across institutions, dependence on funds from external parties, and limited quantitative documentation on both human and material loss, which may weaken the adaptive capacity of the system. More efforts are therefore needed in order to improve the adaptive capacity and, thus, the adaptive governance at Mt. Merapi. This study represents a significant step toward enhancing our understanding of the adaptive governance approach in developing countries.

Keywords: adaptive governance; adaptive capacity; natural disasters; qualitative analysis; Indonesia.

\section{Introduction}

Natural hazards have the potential to impose significant social and economic costs. For the period 1980-2003, the Intergovernmental Panel on Climate Change [1] estimates that the economic loss due to natural disasters reached USD 1 trillion. We underline the difference between natural hazards, which are geophysical events such as volcanic eruptions, and disasters, which involve the interaction of natural hazards with social systems [2-7]. While hazards themselves cannot be prevented, the damage induced by these extreme events may be disastrous, if they cannot be significantly reduced. By "hazard", we mean a threat. Hazard is broadly defined as "a potentially damaging physical event, phenomenon or human activity that may cause the loss of life or injury, property damage, social and economic disruption or environmental degradation" [8]. Hence, a hazard is understood as some influence that may adversely affect a valued attribute of a system. A hazard is generally but not always external to the system under consideration [8]. Besides, the term "disaster" is what we refer to when a major event hits unprepared population. Alexander (2000) makes the point that disaster is usually juxtaposed with resilience: "it is a convulsion in the social system but not necessarily (indeed not usually), a decisive one". Acting on variable scales and leading to different consequences, disasters remain subjective inasmuch it is "what its victims and participants perceive it to be" [9]. According to the Center for Research on the Epidemiology for Disasters (CRED), an event qualifies as a disaster if at least one of the following criteria is fulfilled: 10 or more fatalities are reported; 100 or more people are reported affected, injured, and/or homeless; the government declares a state of emergency; or the government requests international assistance [10]. Moreover, a disaster is a unique event. Each time one occurs, the ingredients, the controlling parameters and the outcome variables are present in unique mixtures. But disasters are also subject to generalization [9].

In general, governance consists of institutional structures, and is concerned with the ways in which societies can organize themselves to accomplish their goals [11]. The concept of governance can be related to a given socio-ecological system that is potentially exposed to 
different hazards. By system we mean an organization, such as a coupled human-environment system, a population group, an economic sector, a geographical region, or a natural system. This notion of system was put forward by Füssel (2007) as the main component of the assessment framework for the concept of vulnerability [8]. The governance of a system refers to mechanisms by which the agents articulate their interests in order to accomplish their goals (e.g. conservation of natural resources, management of natural hazards). The governance refers also to institutions that influence the exercise of power within the concerned entities (e.g. a firm, a multinational company, a country or a region). Finally, the governance of a system can be described by a participatory interaction among stakeholders at all levels (e.g. the public and private sector, civil society and international organizations) [12].

In particular, environmental governance is the system of institutions, including rules, laws, regulations, policies, social norms, and organizations involved in governing environmental resource use and/or protection. There are a variety of different approaches, one of them, emergent, being adaptive governance [13]. The adaptive governance consists in social structures and processes linking individuals, organizations, agencies and institutions at multiple organizational levels [14-15]. This governance model considers policies and management approaches to be part of a knowledge accumulation process or learning process that results in new approaches that are better able to accommodate uncertainty and surprise [16-18]. Therefore, an adaptive governance approach is put forward as an alternative method of managing complex social-environmental problems including disasters [19-20]. Accordingly, Djalante et al. (2012) stated: "Disaster Risk Reduction is a systematic approach to manage disaster risks while adaptive governance is suggested as an alternative approach for governing complex problems such as disasters" [21].

In the field of natural disasters, adaptive governance aims to improve the adaptive capacity of a system by promoting learning processes from the results of management strategies that have already been implemented [16,17,18,22]. In this respect, the adaptive capacity of a system has emerged from a conceptual distinction between "exploitation", that is, the capacity to benefit from existing forms of collective action, and "exploration", that is, the capacity of governance to nurture learning and experimentation [23-24]. In other words, the improvement of the adaptive capacity of a system seems to be the main objective of an adaptive governance model. The Intergovernmental Panel on Climate Change [1] defines the adaptive capacity as the ability of a system to adjust to climate change, mitigate potential damages, benefit from opportunities, or to cope with consequences. However, components determining adaptive capacity and resilience are not easily separated. This article provides insights into actions that could be taken to improve the adaptive capacity of a system that faces disasters.

A growing number of researchers argue that the adaptive governance can increase resilience to natural hazards. Folke et al. (2005) presented adaptive governance as the social contexts necessary to actively manage resilience in social-ecological systems [20]. The concept of resilience has emerged in risk assessment in order to account for the adaptive capacity of urban systems $[9,25]$. This concept of resilience is increasingly associated with research in vulnerability, and adaptive capacity [26-27]. We understand resilience as the ability of a system potentially exposed to hazards to withstand perturbations or shocks [28-29], by resisting or changing in order to reach and maintain an acceptable level of functioning and structure [30-31]. Djalante et al. (2011) highlighted the four characteristics of adaptive governance that are important to help increase 
resilience to natural hazards [32]. These are polycentric and multilayered institutions, participation and collaboration, self-organization and networks, and learning and innovation. Adger et al. (2005) suggested that a multilevel governance system for disaster management enables enhancement of capacity to deal with uncertainties through mobilization of different sources of resilience [33]. Taking the example of the 2004 Indian Ocean tsunami, they argued that the existence of formal and informal institutions as well as large-scale international response helped the affected countries to cope with and recover from the impacts quicker and better, and even permitted the use of the tsunami as a window of opportunity for building long-term community resilience. Based on similar cases, a report by the United Nations Development Program (UNDP) revealed that the Indonesian national platform for disaster risk reduction was formed smoothly due to the existence of a previous analogous entity supported by the recent law 24/2007 on Disaster Management [34].

This article investigates the adaptive capacity and thus the adaptive governance around the Mt. Merapi volcano system. This volcano, located in Central Java, is one of the most active and dangerous composite volcanoes of Indonesia [35] since its eruptions occur every 2-6 years on average over the past 100 years and it is home to 1.4 million people [36-37]. The volcano is located in two provinces (Central Java and Yogyakarta Special Region) and in four districts (Boyolali, Magelang and Klaten districts belong to Central Java Province and Sleman district belongs to Yogyakarta Special Region) (Figure 1). The focus of our study is the OctoberNovember 2010 volcanic eruption of Mt. Merapi whose Volcanic Explosivity Index of 4 (on a scale of 1 to 8) has led researchers to call this eruption the largest ever since 1872 in Java [38]. Data from the National Disaster Management Agency (BNPB, Badan Nasional Penanggulangan Bencana) indicate that after the 2010 Merapi eruption, a total of 367 people were killed and another 277 injured [39]. The evacuation operation led to displacement of almost 400,000 people living within $20 \mathrm{~km}$ from the summit for one and a half months [40]. However, after the eruptive phase, another threat endangered local communities: rain-triggered lahars. The Indonesian term "lahar" is used for a mixture of debris and water, other than stream flow, that flows on volcano slopes at relatively high speed [41]. Rain-triggered lahars devastated several villages on the west and south flank of Merapi in 2011 and 2012 [42-43].

The Mt. Merapi case study is of major interest as it broadens our knowledge regarding the adaptive capacity in developing countries that face natural disasters, in particular as the risk management system in Merapi has proven to be successful in previous disasters. The Center for Volcanology and Geological Hazard Mitigation (CVGHM) displayed an updated hazard map for Merapi, as an input for contingency planning that took place in 2009 [41]. However, the rapid onset and large magnitude of the 2010 eruption of Merapi posed significant challenges for the adaptive capacity of Mt. Merapi. Indonesian researchers and international teams have extensively studied Mt. Merapi volcano, leading to improved understanding of many aspects of the volcanic eruptive processes and aftermath [38]. Recently, Mei et al. [40] studied the evacuation management system of the 2010 eruption of Merapi. But, to our knowledge, none of these studies has explicitly highlighted the governance system that might affect the way in which local communities cope with volcanic eruptions. 
The study of governance appears to be a key parameter in the management of large natural disasters. Since the eruption of Mt. Pinatubo in the Philippines in 1992, much experience has been gained to manage large volcanic crises by creating risk zoning maps, improving communications, targeting evacuations and rehousing [44]. These lessons found an application in cases as diverse as the Ubinas eruption in Peru, which lasted three years from 2006 to 2008 and resumed in 2013. In that circumstance, institutions in charge of risk management had to adapt and demonstrate their agility [45]. The creation of hazard zone maps as well as the preparation of contingency plans by local authorities appeared to be a key point. Another interesting case study is the Kelut eruption in Indonesia in 2007, which was sudden. Risk management efforts suffered from an inability of institutions to take decisions while the communication between the population and the authorities failed [46]. These recent case studies need to be complemented by an in-depth analysis of a very large eruption in a densely populated area, in a context where governance is already set up at the time of the crisis. The main question is to understand whether institutions in charge of the risk management exhibit an adaptive capacity to face such challenge.

The methodology of this article consists of literature review and analysis of qualitative data survey. Our field survey is based on face-to-face interviews, conducted from January to April 2011, just following the eruption in the Mt. Merapi area. The collected information was analyzed both manually and by using the text analysis software Tropes ${ }^{\circledR}$. The software's statistical and linguistic algorithms enable researchers to see connections and relationships in respondents' answers. Such discourse analysis aims at facilitating the understanding of the adaptive capacity of institutions in charge of risk management.

The introduction presents the problem and states the objectives of this study. Section 2 describes the material and the methodology. Section 3 shows the main findings. Section 4 discusses the hypotheses and limitations of the study, and section 5 highlights the main results.

\section{Material and method}

Our methodology includes a literature review and analysis of qualitative data survey. We developed a general assessment framework of the adaptive capacity of a system with six interrelated parameters, which complement one another (Table 1). This paper presents a generally applicable assessment framework for the adaptive capacity of a system in the field of disasters that combines six fundamental parameters: context or system description, technology, infrastructure, institutions, information and skills, and economic and financial resources.

Earlier attempts at studying disasters were limited to a specific approach, with a particular focus on environmental, natural and industrial disasters. In this respect, we can cite Füssel [8] who underlined the importance of a system, as the main component of the assessment framework for the concept of vulnerability to climate change. Surono et al. [39] stressed on the technology component of a system and showed that the magnitude of precursory signals (seismicity, ground deformation, gas emissions) were proportional to the large size and intensity of the $2010 \mathrm{Mt}$. Merapi eruption. Mei et al. [40] highlighted the infrastructure and logistics conditions during the 2010 evacuations at Merapi volcano. Baker and Refsgaard [16] and Chau et al. [47] studied, 
respectively, the case of the Katrina hurricane and the extreme flood events in Vietnam. They both concluded that large-scale disasters require increased coordination and higher levels of institutional flexibility. Kuhlicke and Steinführer [31] emphasized in their report the role of information exchange in risk reduction programs. Strömberg [10] highlighted economic losses caused by geophysical and hydro-meteorological events. We assembled all these components into one assessment framework. In our opinion, these parameters describe different facets of the adaptive capacity of a system.

Our holistic interpretation of the adaptive governance system seeks a better reconstitution of a given system. This assessment framework can improve our understanding of the extent of input (e.g. internal and external resources, technological level and knowledge) that a system possesses, while dealing with industrial or natural disasters, etc.

The sequence of the chosen parameters is related to the chronological occurrence of disasters. At the pre-disaster phase, we underline the system description, the use of technology, and the presence of appropriate infrastructures. At the disaster phase, we stress on the existence of solid institutions, and the communication of information. At the post-disaster phase, we highlight the importance of economic and financial resources in order to cover possible loss. Each key parameter highlights a specific side of the adaptive capacity of a system, as potentially exposed to hazards (Table 1). For example, the availability of critical infrastructure or the use of appropriate technology is more likely to promote an adaptive capacity of the system.

Here Table 1. Key parameters for an assessment framework of the adaptive capacity of a system.

Then, we apply our assessment framework to the system focused on volcanic risk management, especially around Mt. Merapi volcano in central Java (Figure 1). Indonesia has been deeply affected by a range of disasters in recent years, and has a great "potential" for future disasters.

Here Figure 1. Location, setting of Merapi volcano in central Java and hazard-zone map.

We conducted 18 face-to-face interviews with people in charge of risk management in Indonesia, in February-March 2011, three months after the Mt. Merapi eruption. The main surveys were carried out in the neighbourhood of Mt. Merapi, both in villages affected by the eruption and in the capital of the affected regions (districts of Magelang and Sleman). In order to understand the specificities of the Indonesian system devoted to natural disasters and volcanic risk management, we complemented these surveys with interviews in the neibourghood of Mt. Semeru volcano (regency of Lumajang), another persistently active composite cone located in east Java Island, which shares many characteristics (eruptive activity, hazards, high density of population, etc.) with Mt. Merapi. The combination of the two sites offers an interesting overview of how risk management is perceived and performed in Indonesia, especially in the light of a major eruption widely publicized.

Interviewees were chosen based on the personal experiences of chiefs of villages and planning or rescue staff regarding volcanic risk management and the institutions they depend on. While we could not carry on surveys with the national institutions located in the capital of Indonesia, Jakarta, we were able to survey all relevant institutions at the local scale: districts and sub- 
districts, municipality, village, and hamlets. The survey comprises 41 questions distributed under six themes (Appendix 1): (1) risk of lahars to which the region is exposed (6 questions), (2) management of lahar risk (3 questions), (3) occurrence of a volcanic or lahar disaster (10 questions), (4) improvement of the financial responses to lahar damages (4 questions), (5) decision making process about lahar risk (5 questions), and (6) preparation and planning for projects (13 questions). We note that collected data were translated from Indonesian and Javanese languages into English.

People in charge of risk management consider volcanic eruption as the most important hazard related to their environment. Their education level ranges from primary school to university. The general profile of our interviewees is presented in Table 2 and Table 3.

Here Table 2. General profile of interviewees (gender, age, work status).

Table 3. Detailed profile of interviewees (location and volcano, and task).

We carried out a manual and a computer-based analysis of the content of a questionnaire (Appendix 1). Interviews allowed us a preliminary approach to the adaptive capacity as experienced in the 2010 Merapi crisis. After adding answers to each question in a text file, we used the text analysis software Tropes ${ }^{\circledR}$ (version 8.1). Discourse analysis is particularly pertinent for the analysis of qualitative research [48-50]. The software's statistical and linguistic algorithms clustered and classified the data and identified trends through concept maps or constellations. This generates an accurate word count of references, verbs, adjectives and substantives that would be difficult to achieve using the constant comparative method. The software's algorithms also generate linguistic analyses of the style of the text and connection of concepts for every corpus we analyse. The term "reference" designates one or more words sharing the same root and having similar meanings. Moreover, the software allows a graphic presentation of the relationships of words to a chosen reference.

The area graph (Figure 2) shows the relationships between the reference "catastrophe", one of the most used sentences in our surveys, and other references. In this area graph, each reference appears as a sphere, whose surface is proportional to the number of words it contains. The central reference is "catastrophe". The references on the left are its predecessors, those on the right its successors in the text of our interviewees. The distance between the central class and other classes is proportional to the number of relationships connecting them.

Here Figure 2. Connections between the reference "Catastrophe" and other references.

Accordingly, we note that the two classes "catastrophe" and "communication" are close together, which implies that they share many relationships. Moreover, in the discourse, "communication" and "social groups" are mentioned before the catastrophe, which reflects the importance of collective prevention before a disaster occurs. After a catastrophe, the surveyed people are first aware of population's health. Then, they consider the main problems of river conditions (waterway), communications, food, housing and security. Questions related to law and to business appear to be secondary compared to these fundamental issues. 


\section{Results}

This section will expand our knowledge of the communication linkages around Mt. Merapi, the chronological phases of volcanic eruptions and actions taken around the volcano, and the adaptive capacity in Mt. Merapi system.

\subsection{Communication linkages around Mt. Merapi}

The Law of the Republic of Indonesia Nr. 24/2007 defines objectives of risk mitigation, roles and responsibilities of government and stakeholders, as well as funding sources for disaster management [51]. According to this law the entire management system is placed under the supervision of the President of the Republic in order to manage all types of natural and man made disasters. Furthermore, the power and legitimacy to act is given to the National Board for Disaster Management (BNPB), which was established by the same law. BNPB is represented by local agencies named BPDB (Local Disaster Management Agency) and located at different institutional scales (Province and District). The BNPB does not work individually, but in cooperation with various departments, agencies and institutions. For example, in search and rescue of victims of disasters, BNPB collaborates with the National Army, the National Police, Basarnas (Indonesian Search and Rescue) and PMI (Indonesian Red Cross). To manage displaced persons, the BNPB cooperates with the Ministry of Social Affairs. For mapping areas at risk, the BNPB works with BIG (National Bureau of Spatial Information) and departments and agencies to deal with special risk. In the warning system organization in case of disaster, the BNPB works with the Ministry of Energy and Mineral Resources and BMKG (Meteorogical, Climatology and Geophysics Agency) for geological risks, the Ministry of Public Works, the Ministry of Agriculture, the Ministry of Forestry, LAPAN (National Space Agency) for hydro-meteorogical hazards, supported by studies conducted by the Ministry of Research and Technology, LIPI (institute of Science) and universities across Indonesia. For disaster risk reduction education purposes, the BNPB works also with the Ministry of National Education, Ministry of Religious Affairs and the Ministry of Communication and Media [52]. The mechanism of distribution of donations is based on the Regulations of Chief BNPB No.7 2008. Aid from donors is delivered to the Internally Displaced Persons (IDP) camps, under the coordination of BNPB and BPBD.

The flow diagram of management system and communication linkages, emphasizing connections between scientists, government administrations, private organizations, and the public is presented in Figure 3. The administrative levels in Indonesia are as follows: national, province, district, subdistrict, municipality, and village. A municipality encompasses several villages. In order to monitor volcanic activity, five observatory posts have been installed around the Merapi volcano since 1950's-1970's. Information about the eruptive condition and the behaviour of the volcano is reported from each of the observatory posts to CVGHM's Volcano Investigation and Technology Development Office (BPPTK) and to the Merapi Volcano Observatory (MVO, a section of BPPTK) in Yogyakarta and then transmitted to CVGHM. The information on volcanic activity is regularly reported to local governments (i.e. the head of district). The BPBD is the coordinator of 
crisis management. Thus, the head of district together with BPBD coordinates each department involved in the crisis management. At the local scale, the chiefs of villages together with the chiefs of sub-villages and local organizations, and with the help of army, police, NGOs and volunteers prepare the emergency and evacuation plan. However, if the danger is imminent, the BPPTK can use sirens to inform people directly to evacuate. The volcanic crisis management is organized in each of the districts and is based on the recommendations of the CVGHM [40].

Here Figure 3. Flow diagram of the organisational structure and the communication chains in the area of Mt Merapi volcano.

\subsection{Chronological phases of volcanic eruptions and actions taken at Mt. Merapi}

The review of the chronology of volcanic activity in 2010 and actions taken has enabled us to better understand how the Mt. Merapi system reacted to disasters. The 2010 Merapi eruption began on the 26 of October. In response to the increasing volcanic activity, a number of strategic actions had been taken (e.g. warning and evacuation). At the pre-eruption and the initial eruption stages (from 20 September to 2 October 2010), the actions taken by the CVHM met the population expectations and needs. However, as the eruption lasted about three weeks, the lack of preparedness and readiness for coping with the volcanic activity put into question the adaptive capacity of Mt. Merapi system. The increased eruption intensity led to hundreds of fatalities (inhabitants who refused to evacuate or returned to their villages during the eruption) and to numerous logistics problems (e.g. spontaneous evacuation, insufficient shelters, poorly organised aid distribution).

Overall, we distinguish six chronological stages of the 2010 Mt. Merapi eruption [39,40,52]. These stages are chained in Table 4 with respect to the changes observed in volcanic activity and the undertaken actions. Besides, every explosive eruption of Mt. Merapi volcano is usually followed by frequent rain-triggered lahars in the rainy season, which occur weeks to months after an eruption (between October and May). Triggered lahars reflect the long-term impacts of explosive eruptions. Over 240 rain-triggered lahars were recorded during the 2010-2011 rainy season between October 2010 and May 2011, and 42 at the beginning of the 2011-2012 rainy season between October 2011 and January 2012 [39,42]. Lahars generated avulsions (sudden overbank and shift of the river channel towards another non-flooded channel) on the distal slopes of Merapi volcano, potentially creating major disasters in densely populated areas [42-43].

Here Table 4. Chronological events of volcanic activity, actions taken and loss. Source: this survey $[39,40,52]$.

\subsection{Adaptive capacity of the Mt. Merapi system}

Given the 2010 disaster's magnitude (VEI of 4, volume of 70 million $\mathrm{m}^{3}$ of pyroclastic debris, 367 fatalities and 399,403 internally displaced persons), actors of the disaster management hierarchy (Figure 3) had to deal with a critical situation. Their decisions contributed to mitigate the impact of the disaster (e.g. evacuation operations, information dissemination, and aid distribution). 
Moreover, the total of 367 fatalities is relatively small compared to the number of people $(10,000$ to 20,000 people) who might have died without the evacuations [39]. Given this situation, this section aims at measuring the adaptive capacity in Mt. Merapi system. As noted earlier, the assessment of the adaptive capacity of a system depends on six interrelated parameters. We will measure the role of these parameters, as experienced by our interviewees and noticed in the field. Figure 4 presents various aspects of our fieldwork after the eruption.

Here Figure 4. Various aspects of our fieldwork after the eruption of Mt Merapi.

\subsubsection{System description}

The analysis of our respondents' answers highlights the critical context in which communities operate (Table 5). All respondents confirmed that they have already witnessed a volcanic eruption and a mudflow directly in Indonesia, mostly in 2010 and 2011. The village appears to be the main relevant unit for risk management, even if decisions are taken at an upper level. Information is thus provided directly at the local scale to all people concerned by the volcano. Such proximity is the best way to communicate information that may be acknowledged by local people.

Here Table 5. The most recurrent "References", "Verbs" and "Adjectives" in the themes "Early warning and risk monitoring", as generated by Tropes.

\subsubsection{Technology}

Monitoring and warning systems have been set up in all rivers that drain the flanks of the Mt. Merapi volcano. The early warning system around Mt. Merapi is based on the analysis of instrumental and visual observations for a better accuracy. These two kinds of analyses are complementary because the onset of an eruption can be forecasted using seismographs while the sudden outbreak of a lahar can only be perceived in the field.

For the majority of our respondents (94\%), risk assessment relies on identified indicators, such as rainfall intensity and duration (which leads to an increase in river water level) and delivered information by local residents to the public. These indicators allow them to identify the intensity and the likelihood of the expected hazard. However, they may be subjective or based on rudimentary instruments. A respondent stated that flood might occur "whenever the rain falls heavily". Another respondent added, "As an indicator, there is a water level gauge, measured in high and low river stage, using a light bulb. If the bulb is broken, it means that the water is high". Indeed, a monitoring system existed before the eruption but was severely damaged. During the weeks that immediately followed the eruption, the system was updated and resized to facilitate observations of the volcano and the valleys while improving radio communications. Further, the implication of local youth (supervised by people from NGOs, universities and volcanologists) in lahars risk monitoring and disaster risk reduction becomes important since the awareness of lahars' hazard increases. Local youth helped evacuate residents (especially children, women and elderly people) and kept them away from the flood plain of the rivers. 


\subsubsection{Infrastructure}

Infrastructure facilities (e.g. dams, bridges, public bathing and shelters) are not adequate to cope with large-scale disasters. In the aftermath of the 2010 volcanic eruption, a large number of bridges and roads were destroyed, isolating many villages. For the first time, Merapi eruptions resulted in major disruptions of air traffic in Yogyakarta (2,463 flights were cancelled [40]).

In order to improve this relatively poor infrastructure, a number of projects have been conducted, especially in 2011. The respondents included in our survey provided information regarding seven projects (Table 6) that aim to improve the capacity to cope with future crisis, such as building temporary shelters, evacuating villages, providing clean water, mapping, and determining evacuation routes. Improvement projects are mostly co-financed by national organizations, and NGOs, such as the Government, the Indonesian Red Cross, the Denmark Red Cross, the Japanese government and private organizations.

Here Table 6. The most recurrent "References", "Verbs" and "Adjectives" in the themes "Improvement projects", as generated by Tropes.

People and infrastructure at stake are mostly located in some villages located on the slopes of Mt Merapi, but also in valleys that start on the flanks of the volcano. Because the most affected people usually do not want to move outside their village after the crisis, improvement projects have to be designed close to affected areas but in safe locations. At the time of the surveys, most of these projects were conceived as temporary. The lack of funds has led transitory choices to become perennial decisions. After the 2010 Merapi eruption and lahars, we distinguish between temporary housing (hunian sementara) and permanent housing (hunian tetap) that differ in their locations and construction materials.

\subsubsection{Institutions}

Coordination among institutions is mainly oriented towards relief operations (e.g. information dissemination, financial compensation) and repairing damage (e.g. building shelters) resulting from volcanic eruptions and rain-triggered lahars. The respondents mentioned a number of institutions that we divided into three categories of institutions (Table 7): Local Government (LG), Civil Society Organizations (CSO) and Community Representatives (CR). They underline the presence of International institutions and NGOs, e.g. the Indonesian Red Cross.

Here Table 7. Three categories of institutions are acting around Mt. Merapi.

The respondents included in our survey believe that Local Government (LG) and Community Representatives (CR) are the most important institutions since they are linked to major administrative institutions (e.g. Central Government) and have the legitimacy to act. In addition, some of the respondents consider that the Indonesian Red Cross is the most important institution as it maintains partnerships with other international institutions such as the Danish Red Cross. 
However, others chose Civil Society Organizations (CSO) over LG or CR because they have no bureaucracy constraints and can provide quick support (money, food) to local inhabitants.

According to the respondents, the institutions that should first react when lahars occur are: neighbors, local authorities (village chief, rescue team, personalities), and Sub-District authorities. This indicates a participatory approach that is facilitated by strong social networks and bottom-up relationships. However, a number of limitations persist. The hierarchical system of the Indonesian disaster management (Figure 3) may lead to bureaucracy, which does not favour an early response and may facilitate corruption. Moreover, our respondents asserted that most of constructions are set up illegally and without property rights in areas reported to be dangerous according to contingency plans. Such situation generated conflicts for the compensation and relocation of victims.

\subsubsection{Information and skills}

The dissemination of information among institutions and population is provided by a wide variety of means, persons and localities (Table 8). During the emergency response period in 2010, orders to evacuate were permanently communicated through a variety of direct communication channels (e.g. public meetings, radio and TV announcements) and as a result many thousands of lives could be saved.

Here Table 8. Means and localities used for the dissemination of information, as generated by Tropes software.

Information and skills around Mt. Merapi are generated by a beneficial cooperation between scientists and communities by using reliable scenarios and instruments (e.g. social networks, radio, mobile phones). This self-organization facilitates the dissemination of warnings among people living in hazard-prone areas before the arrival of a lahar. Hence, maps and evacuation plans are regularly updated and posted in villages. As a result, the majority of the respondents $(89 \%)$ believe in the correctness of the delivered information. However, our respondents mentioned a number of limitations, such as imprecise documentation for both human and material loss, and incompleteness of the delivered information. It implies that the authorities give the priority to the study of volcanic hazards compared to the study of vulnerability, which is more complex.

\subsubsection{Economic and financial resources}

Financial resources are a key component for the management of a volcanic crisis. They are needed before an eruption for prevention purposes (education, dams, roads, signs), during an event for emergencies (evacuation, relocation, first aid) and after for recovery (compensation, rehabilitation, improvement projects). However, the lack of economic and financial resources appears to be a weakness for the adaptive capacity at Mt. Merapi. 
In the Indonesian system, financial resources devoted to natural disasters are allocated on a caseto-case basis before and after a disaster [51]. Because resources are not perennial, local institutions have to ask for support from private companies (TV channels) or foreign institutions (NGOs). When a large disaster occurs, the government applies a compensation process that is channeled with a top-down approach as follows: the District, the Sub-District, and the village, then to the victims. Due to bureaucratic constraints, all necessary funds do not arrive in a timely fashion and villages have to rely on solidarity, which is material such as food and clothes. However, for the villages located near to the Merapi summit, many villagers have livestock as saving that they sell during crisis periods. They also have public saving either in cash or livestock [52].

The system could be improved with the generalization of basic mechanisms such as reserve and solidarity funds at the local and national scales. These two solutions are the most cited by the respondents (respectively $46 \%$ and $29 \%$ ). In a developing country, blocking funds for an uncertain use may not be easily understood, but Indonesia faces many eruptions each year at the national scale. Insurance policies are not considered as a reliable way to hedge risk because of the amount of premiums compared to the standard of living and the cultural change they represent [53]. At the moment, only a micro-insurance scheme devoted to flood risk is available in some parts of Indonesia [54]. Besides, a large number of the respondents (59\%) cannot formulate any estimate of the human loss that an eruption or a lahar can cause. In order to estimate the amount of material and human loss, inhabitants refer to maps, which indicate the number of houses located near the river.

\section{Discussion}

Our analysis has revealed challenges that a major disaster such as a rapid and larger-than-expected eruption may pose and solutions needed to improve the capacity of a system to cope with future crises. Lessons learned at Mt Merapi after the 2010 eruption may be useful to improve the ability of risk management institutions to deal with volcanic eruptions and other disasters. Based on this analysis, Table 9 summarizes the facilitating and limiting factors to an "improved" or "more efficient" adaptive capacity of a system.

Here Table 9. The assessment framework of the adaptive capacity around Mt. Merapi volcano.

Table 9 highlights different ways by which the adaptive capacity, and thus the adaptive governance, of a system can be improved. For effective response in the future, it is necessary to work further with communities to develop strategies that they will accept and comply with. Several steps can be taken in the future to improve future evacuations, such as: (1) a more complete integration of disaster risk reduction education into school curriculum, (2) a development of an updated disaster database which includes loss, (3) a better and maintained facilities (roads, IDP camps, etc.), (4) a more effective dissemination of accurate information, and (5) an elaboration of multiple hazard scenarios for contingency not only for pyroclastic density currents (PDCs) but also for lahars at local scale (desa/dusun). 
Besides, inhabitants living on and around Mt. Merapi are likely to have adapted in various ways to their hazardous environment. Interpretations of risks are shaped by their own experience, personal feelings and values, cultural beliefs and interpersonal and societal dynamics [55]. The available choices in everyday-life are perceived to present greater threats to survival than the threat posed by natural hazards. The need for securing daily livelihoods prevails over volcanic risk perception while religious beliefs enable people to cope with the threat by providing alternative explanations at the time of a disaster [56]. Furthermore, lahars produced by rains on the Merapi volcano bring a valuable resource to communities of villagers, who are ready to increase their exposure to hazard by quarrying deposits in valleys filled by lahar deposits.

However, results provided in this study may be very context-dependent. Our sample of 18 face-toface interviews with key actors of the management of volcanic crisis, especially the 2010 Merapi eruption, does not pretend to be representative of the population living around Mt. Merapi. Despite these limitations, our results stay in line with other studies undertaken on the eruption and its management. According to Mei et al. [40], the 2010 Merapi volcano eruption provided another example of a successful evacuation. Such a rapid evacuation and displacement of hundreds of thousands of people had not been tested before in a highly hazardous explosive eruption [57]. An efficient community-based hazard management prevented significant human loss [42].

\section{Conclusion}

This study has examined the adaptive capacity and the adaptive governance of a system. We have developed and applied an assessment framework of the adaptive capacity of a system, potentially exposed to disasters using six complementary criterias. The case study focused on Merapi in the densely populated island of Java, Indonesia, which can be considered as an example of adaptive governance facing the frequency of explosive eruptions of this volcano. The 2010 Merapi eruption was much larger and longer than anticipated by contingency planners. Before the 2010 eruption, the contingency plan for each district (kabupaten) was only limited on PDC scenario. The choice of this case study seems to be relevant because the 2010 Merapi eruption has caused various consequences, including environmental degradation, loss of life and property. We were able to carry out surveys with the main actors of the Merapi rescue system only three months after this major event.

(1) During the crisis, confusion and disruptions of networks and infrastructures revealed the need to prepare for larger-than-normal eruptions. Our results showed that preparation before the eruption was critical to the management of the eruption because lives could be saved and people at risk could be relocated. The adaptive capacity of Merapi system could be evaluated as quiet acceptable. However, rating an adaptive governance system as successful is not only based on the number of lives saved, but also on the way actors behave and their reaction during the crisis (evacuation, transportation, first aid, relocation, etc.).

(2) Enhancement of the adaptive capacity factors may improve the Merapi governance system in order to deal with future eruptions. In particular, a greater emphasis should be made on the 
evaluation of overall vulnerability around the volcano, leading to a rapid enlargement of the restricted zone, and on the development of a financial system able to cope more efficiently with disasters.

(3) The theoretical aspect of our research leads to a deep understanding of the concept of adaptive governance. In applying the adaptive capacity assessment framework to the aftermath of the 2010 Merapi eruption, this article combines both theoretical and practical aspects.

This work represents a contribution to interdisciplinary research for the management of natural and man made disasters (e.g. environmental and industrial disasters). The assessment framework of the adaptive capacity, however, is applicable to any system of equal complexity. Government, policy makers, and other stakeholders may use this approach in developing and assessing critical reforms in the decision-making process.

Acknowledgements

This study was undertaken with the support of the French National Research Agency (ANR) under the framework of the project "Laharisk". We thank Alix Hague for the English editing.

\section{References}

[1] IPCC (Intergovernmental Panel on Climate Change). Forth Assessment Report (AR4), Climate Change 2007: Impacts, Adaptation and Vulnerability. Contribution of Working Group II to the Fourth Assessment Report of the Intergovernmental Panel on Climate Change. M.L. Parry, O.F. Canziani, J.P. Palutikof, P.J. van der Linden and C.E. Hanson, Eds (Cambridge University Press, Cambridge, UK), 2007.

[2] I. Alcántara-Ayala, Geomorphology, Natural Hazards, Vulnerability and Prevention of Natural Disasters in Developing Countries, Geomorphology 47 (2002) 107-124.

[3] C. Cohen, E.D. Werker, The Political Economy of "Natural" Disasters, The Journal of Conflict Resolution 52(6) (2008) 795-819.

[4] D. Henstra, G. McBean, Canadian Disaster Management Policy: Moving toward a Paradigm Shift?, Canadian Public Policy / Analyse de Politiques 31(3) (2005) 303-318.

[5] D.A. McEntire, Triggering Agents, Vulnerabilities and Disaster Reduction: Towards a Holistic Paradigm, Disaster Prevention and Management 10(3) (2001) 189-196.

[6] D.S. Mileti, Disasters by Design: A Reassessment of Natural Hazards in the United States. Joseph Henry Press, Washington, DC, 376, 1999.

[7] P. O'Keefe, K. Westgate, B. Wisner, Taking the naturalness out of natural disasters, Nature 260 (1976) 566-567.

[8] H. M. Füssel, Vulnerability: A generally applicable conceptual framework for climate change research, Global Environmental Change 17(2) (2007) 155-167. 
[9] D. Alexander, Confronting Catastrophe: New perspectives on natural disasters. Terra Publishing, England, Chapter 2, Definitions, 7-22, 2000.

[10] D. Strömberg, Natural Disasters, Economic Development, and Humanitarian Aid, The Journal of Economic Perspectives 21(3) (2007) 199-222.

[11] R.C. De Loë, D. Armitage, R. Plummer, S. Davidson, L. Moraru, From Government to Governance: A State-of-the-Art Review of Environmental Governance, Final Report, Prepared for Alberta Environment, Environmental Stewardship, Environmental Relations, Rob De Loë Consulting Services, Guelph, Ontario, 67, 2009.

[12] D. Bakkour, Un essai de définition du concept de gouvernance, WP LAMETA, «Études et synthèses » series, ES no 2013-05, (2013) 40. http://www.lameta.univmontp1.fr/Documents/ES2013-05.pdf

[13] B. C. Chaffin, H. Gosnell, B. A. Cosens, A decade of adaptive governance scholarship: synthesis and future directions, Ecology and Society 19(3) (2014) 56. http://dx.doi.org/10.5751/ES-06824-190356

[14] L. Gunderson, S. Light, Adaptive Management and Adaptive Governance in the Everglades Ecosystem, Policy Sciences 39(4) (2006) 323-334.

[15] F. H. Norris, S. P. Stevens, B. Pfefferbaum, K. F. Wyche, R. L. Pfefferbaum, Community resilience as a metaphor, theory, set of capacities, and strategy for disaster readiness, American Journal of Community Psychology 41 (2008) 127-150.

[16] D. Baker, K. Refsgaard, Institutional development and scale matching in disaster response management, Ecological Economics 63 (2007) 331-343.

[17] C. S. Holling, From complex regions to complex worlds, Ecology and Society 9(1) (2004) 11.

[18] P. Olsson, Building Capacity for Resilience in Social-Ecological Systems, PhD thesis, Stockholm University, 2003. http://albaeco.com/htm/pdf/PerOlssonkappa.pdf

[19] T. Dietz, E. Ostrom, P. C. Stern, The Struggle to Govern the Commons, Science 302 (2003) 1907-1912.

[20] C. Folke, T. Hahn, P. Olsson, J. Norberg, Adaptive governance of social-ecological systems, Annual Review of Environment and Resources 30 (2005) 441-473.

[21] R. Djalante, Adaptive governance and resilience: the role of multi-stakeholder platforms in disaster risk reduction, Natural Hazards Earth System Science 12 (2012) 2923-2942, doi:10.5194/nhess-12-2923-2012.

[22] R. D. Kusumastuti, Viverita, Z. A. Husodo, L. Suardi, D. N. Danarsari, Developing a resilience index towards natural disasters in Indonesia, International Journal of Disaster Risk Reduction 10 (2014) 327-340. 
[23] J. March, Exploration and Exploitation in Organizational Learning, Organization Science 2(1) (1991) 71-87.

[24] J. March, J. Olsen, Elaborating the 'New Institutionalism', WP No.11, Center for European studies, 2005. http://unesco.amu.edu.pl/pdf/olsen2.pdf

[25] S. Lhomme, G. Djament-Tran, Penser la résilience urbaine, in DjamentTran G. et ReghezzaZitt M. (dir.), Résiliences urbaines : les villes face aux catastrophes, coll. Fronts pionniers, Paris, Editions Le Manuscrit, 2012, 13-46.

[26] G. C. Gallopín, Linkages between Vulnerability, Resilience, and Adaptive Capacity. Global Environmental Change 16 (3) (2006) 293-303.

[27] F. Miller, H. Osbahr, E. Boyd, F. Thomalla, S. Bharwani, G. Ziervogel, B. Walker, J. Birkmann, S. van der Leeuw, J. Rockstrom, J. Hinkel, T. Downing, C. Folke, D. Nelson, Resilience and Vulnerability: Complementary or Conflicting Concepts? Ecology and Society 15(3): Article No. 11 (2007).

[28] C. S. Holling, Resilience and stability of ecological systems, Annual Review Ecology and Systematics 4 (1973) 23.

[29] F. Berkes, Understanding uncertainty and reducing vulnerability: Lessons from resilience thinking, Natural Hazards 41(2) (2007) 283-295.

[30] United Nations International Strategy for Disaster Risk Reduction (UNISDR), Hyogo Framework for 2005-2015: Building the Resilience of Nations and Communities to Disasters, (2005) 1-25.

[31] C. Kuhlicke, A. Steinführer, Social Capacity Building for Natural Hazards. A Conceptual Frame. CapHaz-Net WP1 Report, Helmholtz Centre for Environmental Research - UFZ: Leipzig, 50, 2010.

[32] R. Djalante, C. Holley, F. Thomalla, Adaptive governance and managing resilience to natural hazards, International Journal of Disaster Risk Sciences 2 (2011) 1-14. http://dx.doi.org/10.1007/s13753-011-0015-6

[33] N. Adger, T. Hughes, C. Folke, S. Carpenter, J. Rockstrom, Social-Ecological Resilience to Coastal Disasters, Science 309 (2005) 1036-42.

[34] UNDP (United Nations Development Program) Indonesia, Lessons Learned: Indonesia's Partnership for Disaster Risk Reduction, the National Platform for DRR and the University Forum. Jakarta: United Nations Development Program-Indonesia 2008. http:// www.undp.or.id/pubs/docs/Lessons\%20Learned\%20Indonesias\%20partnership\%20for\%20 Disaster\%20Risk\%20Reduction.pdf

[35] J. C. Thouret, F. Lavigne, K. Kelfoun, S. Bronto, Toward a revised hazard assessment at Merapi volcano, Central Java, Journal of Volcanology and Geothermal Research 100 (2000) 479-502. 
[36] F. Lavigne, J. C. Thouret, B. Voight, H. Suwa, A. Sumaryono, Lahars at Merapi volcano, Central Java: an overview, Journal of Volcanology and Geothermal Research 100 (2000) 423-456.

[37] C. Newhall, S. Bronto, B. Alloway, N. G. Banks, I. Bahar, M. A. DelMarmol, R. D. Hadisantono, R. T. Holcomb, J. McGeehin, J. N. Miksic, M. Rubin, S. D. Sayudi, R. Sukhyar, S. Andreastuti, R. I. Tilling, R. Torley, D. Trimble, A. D. Wirakusumah, 10,000 years of explosive eruptions on Merapi volcano, Central Java: archaeological and modern implications, Journal of Volcanology and Geothermal Research 100 (2000) 9-50.

[38] Ph. Jousset, J. Pallister, Surono, eds., Special Issue "Merapi eruption", Journal of Volcanology and Geothermal Research 261 (2013) 387.

[39] P. Surono, P. Jousset, J. Pallister, M. Boichu, F. Buongiorno, A. Budisantoso, F. Costa, S. Andreastuti, F. Prata, D. Schneider, L. Clarisse, H. Humaida, S. Sumarti, C. Bignami, J. Griswold, S. Carn, C. Oppenheimer, F. Lavigne, The 2010 explosive eruption of Java's Merapi volcano-A '100-year' event”, Journal of Volcanology and Geothermal Research 241-242 (2012) 121-135.

[40] E. T. W. Mei, F. Lavigne, A. Picquout, E. De Bélizal, D. Brunstein, D. Grancher, J. Sartohadi, N. Cholik, C. Vidal, Lessons learned from the 2010 evacuations at Merapi volcano, Journal of Volcanology and Geothermal Research 261 (2013) 348-365.

[41] F. Lavigne, J. C. Thouret, Sediment transportation and deposition by rain-triggered lahars at Merapi Volcano, Central Java, Indonesia, Geomorphology 49 (2002) 45-69.

[42] E. De Bélizal, F. Lavigne, D. Sri Hadmoko, J. P. Degeai, G. Aria Dipayana, B. Wahyu Mutaqin, M. Aris Marfai, M. Coquet, B. Le Mauf, A. K. Robin, C. Vidal, N. Cholik, N. Aisyah, Rain-triggered lahars following the 2010 eruption of Merapi volcano, Indonesia: A major risk, Journal of Volcanology and Geothermal Research 261 (2013) 330-347.

[43] A. Solikhin, J. C. Thouret, SC. Liew, A. Gupta, D. Sri Sayudi, JF. Oehler, Z. Kassouk, High-spatial resolution imagery helps track the effects and deposits of the large (VEI 4) 2010 Merapi Volcano eruption, Bulletin of Volcanology, 77: 20, DOI 10.1007/s00445-0150908-0

[44] J. C. Tayag, RS. Punongbayan, Volcanic disaster mitigation in the Philippines: experience from Mt Pinatubo, Disasters 18 (1994) 1-15.

[45] M. Rivera, J. C. Thouret, J. Marino, R. Berolatti, J. Fuentes, Characteristics and management of the 2006-2008 volcanic crisis at the Ubinas volcano (Peru), Journal of Volcanology and Geothermal Research 198 (2010) 19-34.

[46] E. De Bélizal, F. Lavigne, J. C. Gaillard, I. Pratomo, J. C. Komorowski, The 2007 eruption of Kelut volcano (East Java, Indonesia): Phenomenology, crisis management and social response, Geomorphology 136(1) (2012) 165-175.

[47] V. Ngoc Chau, J. Hollanda, S. Cassells, Institutional structures underpinning flood management in Vietnam, International Journal of Disaster Risk Reduction 10 (2014) 341348. 
[48] D. Bonet, Réflexions sur les relations interorganisationnelles: du dépassement de l'antagonisme conflit-coopération à l'émergence de nouvelles démarches collaboratives, HDR, Centre de Recherche sur le Transport et la Logistique CRET-LOG, Université de la méditerranée, 2008.

[49] R. Ghiglione, A. Landré, M. Bromberg, P. Molette, L'analyse automatique des contenus, Paris, Dunod, 1998.

[50] M. Hajer, W. Versteeg, A decade of discourse analysis of environmental politics: Achievements, challenges, perspectives, Journal of Environmental Policy and Planning 7(3) (2005) 175-184.

[51] G. Enjolras, R. Kast, J. C. Thouret, M. Nagata, B. Prihatminingtyas, J. Uchuchoque, Management systems against flood hazard and risk: The Indonesian and Peruvian experiences, Contributed paper to the IWA-WCE World Congress on Water, Climate and Energy, 13-18 May 2012, Dublin, Ireland, 2012.

[52] E. T. W. Mei, Gestion des évacuations lors des crises volcaniques : étude de cas du volcan Merapi, Java, Indonésie, $\mathrm{PhD}$ Thesis (unpublished), Laboratory Espaces, sociétés, aménagement, Laboratory géographie physique "Pierre Birot", Université Paris 1, (2013) 333.

[53] A. Arfan, Prospects and Constraints of General Insurance Business in the Islamic Law Perspective, De Jure 1(1) (2009) 63-70.

[54] S. Surminski, D. Oramas-Dorta, Flood insurance schemes and climate adaptation in developing countries, International Journal of Disaster Risk Reduction 7 (2014) 154-164.

[55] J. R. Eiser, A. Bostrom, I. Burton, D. M. Johnston, J. Mc Clure, D. Paton, J. V. D. Pligt, M. P. White, Risk interpretation and action: A conceptual framework for responses to natural hazards, International Journal of Disaster Risk Reduction 1 (2012) 5-16.

[56] F. Lavigne, B. De Coster, N. Juvin, F. Flohic, J. C. Gaillard, P. Texier, J. Morin, J. Sartohadi, People's behaviour in the face of volcanic hazards: Perspectives from Javanese communities, Indonesia, Journal of Volcanology and Geothermal Research 172 (2008) 273287.

[57] S. Jenkins, J. C. Komorowski, P. J. Baxter, R. Spence, A. Picquout, F. Lavigne, P. Surono, The Merapi 2010 eruption: An interdisciplinary impact assessment methodology for studying pyroclastic density current dynamics, Journal of Volcanology and Geothermal Research 261 (2013) 316-329.

Table captions

Table 1. Key parameters for an assessment framework of the adaptive capacity of a system.

\begin{tabular}{|l|l|}
\hline \multicolumn{1}{|c|}{ Parameters } & \multicolumn{1}{|c|}{ Explanation } \\
\hline $\begin{array}{c}\text { 1. System } \\
\text { description }\end{array}$ & $\begin{array}{l}\text { Shows whether or not populations are aware of the risk at stake. It } \\
\text { comprises the geographical component (locality), the community (region or }\end{array}$ \\
\hline
\end{tabular}




\begin{tabular}{|c|c|}
\hline & $\begin{array}{l}\text { population group), the hazard, the valued attributes (human life, properties, } \\
\text { and agricultural land) and the time scale (short or long-term consequences). }\end{array}$ \\
\hline 2. Technology & $\begin{array}{l}\text { Indicates the technical side of a system. It consists of the implementation } \\
\text { and the use of technology while dealing with hazards, such as warning } \\
\text { systems, detection instruments, programs, maps and communication tools. }\end{array}$ \\
\hline 3. Infras & $\begin{array}{l}\text { Consists of listing whether or not appropriate infrastructure is available. } \\
\text { Such listing may contain improved engineering for buildings, dams, } \\
\text { shelters, hospitals, sanitization facilities or roads. }\end{array}$ \\
\hline 4. Institutions & $\begin{array}{l}\text { Detects the existence of formal and informal arrangements. It consists of } \\
\text { detecting for what institutions exist on purpose, and for whose interest they } \\
\text { exist, persist, or change. Examples of institutions are: land-use planning } \\
\text { and management to prevent settlement in dangerous areas, enforcement of } \\
\text { building codes and enforcement of property right laws. }\end{array}$ \\
\hline $\begin{array}{l}\text { 5. Information } \\
\text { and skills }\end{array}$ & $\begin{array}{l}\text { Indicates the knowledge and the capacity level of a system to face future } \\
\text { disasters. A key element is to understand if the likelihood of a disaster, i.e. } \\
\text { its precursory event, is sufficient to warrant the mobilization of resources } \\
\text { (e.g. the precautionary principle). }\end{array}$ \\
\hline $\begin{array}{l}\text { 6. Economic and } \\
\text { financial } \\
\text { resources }\end{array}$ & $\begin{array}{l}\text { Indicates whether or not a system is able to hedge possible loss from } \\
\text { disaster. Among economic and financial resources, this encompasses: } \\
\text { available funds, public saving in cash or livestock, budgetary situation, } \\
\text { compensation, and risk sharing through insurance, reinsurance, and other } \\
\text { financial products (bonds, actions, credits, and derivatives). }\end{array}$ \\
\hline
\end{tabular}

Key: The choice of the six key parameters is influenced by the literature review presented in section 2 . The adaptive capacity of a system is evaluated by assessing both the facilitating and limiting factors for each of the six parameters of the assessment framework.

Table 2. General profile of interviewees (gender, age, work status).

\begin{tabular}{|l|l|}
\hline & Respondents \\
\hline Gender & 16 males and 2 females \\
\hline Age & 25 to 60 (average 45 years old) \\
\hline Work status & Positions related to risk management process \\
\hline
\end{tabular}


Table 3. Detailed profile of interviewees (location and volcano, and task)

\begin{tabular}{|l|l|}
\hline Location and volcano & Task \\
\hline Magelang (city) Mount Merapi & Head of SAR, Magelang \\
\hline Kaliurang (village) Mount Merapi & Head of SIBAT, Kaliurang \\
\hline Yogyakarta (city) Mount Merapi & Professor, Head of PSBA \\
\hline Srumbung (village) Mount Merapi & Chief of Srumbung village \\
\hline Blongkeng (village) Mount Merapi & Secretary of Blongkeng village and shelter management \\
\hline Agomulyo (village) Mount Merapi & Head of social and management section in Agomulyo village \\
\hline Bronggang (hamlet) Mount Merapi & Chief of Bronggang hamlet \\
\hline Kaliurang (village) Mount Merapi & Retired \\
\hline Mt. Sawur Mount Semeru & Staff on Mt. Sawur observatory \\
\hline Lumajang (city) Mount Semeru & Control for improvement and expansion \\
\hline Lumajang (city) Mount Semeru & Engineer \\
\hline Lumajang (city) Mount Semeru & SAR Trainer \\
\hline Candipuro (village) Mount Semeru & Planning Staff \\
\hline $\begin{array}{l}\text { Pasrujambe (village) Mount } \\
\text { Semeru }\end{array}$ & Flood information official on Besuksat River, member of rescue team \\
\hline $\begin{array}{l}\text { Pasrujambe (village) Mount } \\
\text { Semeru }\end{array}$ & Staff in Pasrujambe Sub-District \\
\hline $\begin{array}{l}\text { Pasrujambe (village) Mount } \\
\text { Semeru }\end{array}$ & Chief of Pasrujambe village \\
\hline Kamituwo (hamlet) Mount Semeru & Chief of Kamituwo hamlet \\
\hline Pronojiwo (village) Mount Semeru & Entrepreneur \\
\hline Abbreviations ang
\end{tabular}

Abbreviations and acronyms:

SAR: National Search and Rescue Agency.

PSBA UGM: Research Center for Disasters, Gadjah Mada University, Yogyakarta.

Key: As shown in the table, our interviewees have gained experience in disaster management on the slopes of Mt. Semeru and Mt. Merapi, two volcanoes subject to frequent eruptions whose slopes are regurlay affected by lahars and mudflows. 
Table 4. Chronological events of volcanic activity, actions taken, and loss. Source: this survey, $[39,40,52]$.

\begin{tabular}{|c|c|c|c|c|}
\hline & $\begin{array}{l}\text { Warning level* - } \\
\text { Radius of danger } \\
\text { zone (KRB) }\end{array}$ & Volcanic activity & Actions taken & $\begin{array}{c}\text { Loss, } \\
\text { IDPSs**, and problems faced }\end{array}$ \\
\hline \multicolumn{5}{|c|}{ 1. Pre-eruption stage (20 september-25 october 2010 ) } \\
\hline Sep. $20^{\text {th }}$ & $\begin{array}{l}\text { II- } \\
10 \mathrm{~km}\end{array}$ & \multirow{3}{*}{$\begin{array}{l}\text { Dramatic increase } \\
\text { in all monitored } \\
\text { parameters }\end{array}$} & CVGHM***: need to evacuate tens of thousands of people. & \multirow{3}{*}{$\begin{array}{l}\text { No human and material loss. } \\
\text { Mbah Marijan, the "gatekeeper } \\
\text { of Merapi" refused to leave his } \\
\text { house in Kinahrejo. } \\
\text { Some refusals to evacuate } \\
\text { despite orders. }\end{array}$} \\
\hline Oct. $21^{\text {th }}$ & $\begin{array}{c}\text { III- } \\
10 \text { km }\end{array}$ & & Release of information related to preparation for evacuation. & \\
\hline Oct. $25^{\text {th }}$ & $\begin{array}{l}\text { IV- } \\
10 \mathrm{~km}\end{array}$ & & $\begin{array}{l}\text { Maximal level of the warning system. } \\
\text { Local authorities: evacuation of persons with special access } \\
\text { and functional needs, the elderly, children and pregnant } \\
\text { women, for the villagers living in KRB III. } \\
\text { CVGHM: warning that there was a high probability of an } \\
\text { unprecedented explosive eruption. }\end{array}$ & \\
\hline \multicolumn{5}{|c|}{ 2. Initial explosion ( 26 october-02 november 2010 ) } \\
\hline Oct. $26^{\text {th }}$ & $\begin{array}{l}\text { IV }- \\
10 \mathrm{~km}\end{array}$ & $\begin{array}{l}\text { First explosive } \\
\text { eruption. } \\
\text { Production of a } 12 \\
\text { km-high ash } \\
\text { plume and } \\
\text { PDCs*****. }\end{array}$ & $\begin{array}{l}\text { CVGHM: order to evacuate } 12 \text { municipalities (total of } \\
24,024 \text { habitants) located in the KRB III. } \\
\text { Local authorities: order to evacuate people in the danger } \\
\text { zone. } \\
\text { BPPTK****: release of monitoring and recommendations } \\
\text { data every six hours. }\end{array}$ & $\begin{array}{l}35 \text { people (Marijan and } 34 \\
\text { others) died. } \\
\text { 22,599 IDPSs. }\end{array}$ \\
\hline Oct. $30^{\text {th }}$ & $\begin{array}{l}\mathrm{IV}- \\
10 \mathrm{~km}\end{array}$ & & $\begin{array}{l}\text { Army, Police and rescue teams: evacuation of the dead and } \\
\text { injured, and searching for missing people. }\end{array}$ & 53,048 IDPSs. \\
\hline \multicolumn{5}{|c|}{ 3. Increased eruption intensity (03-04 november 2010) } \\
\hline Nov. $3^{\text {rd }}$ & $\begin{array}{l}\text { IV- } \\
15 \mathrm{~km}\end{array}$ & & $\begin{array}{l}\text { CVGHM: recommendation to evacuate } 32 \text { municipalities } \\
\text { (total of } 90,325 \text { habitants) located in the KRB III. }\end{array}$ & 76,031 IDPSs. \\
\hline Nov. $4^{\text {th }}$ & $\begin{array}{l}\text { IV- } \\
15 \mathrm{~km}\end{array}$ & $\begin{array}{l}\text { Paroxysmal } \\
\text { eruption took place. }\end{array}$ & $\begin{array}{l}\text { CVGHM: extent of the danger zone to } 20 \mathrm{~km} \text { from the } \\
\text { summit and call for evacuation. }\end{array}$ & $\begin{array}{l}\text { - } 82,701 \text { IDPSs. } \\
\text { - No refugee camps beyond } 20 \\
\text { km to accommodate the IDPs. } \\
\text { Evacuations were taking place } \\
\text { spontaneously. }\end{array}$ \\
\hline \multicolumn{5}{|c|}{ 4. Sustained explosive eruptions ( $05-13$ november 2010 ) } \\
\hline Nov. $5^{\text {th }}$ & $\begin{array}{c}\text { IV- } \\
20 \mathrm{~km}\end{array}$ & $\begin{array}{l}\text { - Paroxysmal } \\
\text { eruptions for } 24 \\
\text { continuous hours. } \\
\text { - Ash fell in the } \\
\text { region west and } \\
\text { south of the vent. } \\
\text { - PDCs reached } 16 \\
\text { km from the } \\
\text { summit in the } \\
\text { Gendol River. }\end{array}$ & $\begin{array}{l}\text { Local authorities of the Sleman district: preparation of a new } \\
\text { IDP camp in Maguwoharjo football stadium (located } 23 \mathrm{~km} \\
\text { from Merapi). }\end{array}$ & $\begin{array}{l}\text { - About } 200 \text { people died. } \\
\text { 239,618 IDPSs. } \\
\text { - CVGHM did not communicate } \\
\text { the list of villages to be } \\
\text { evacuated. } \\
\text { - Misunderstanding by some of } \\
\text { the emergency managers. } \\
\text { - All IDP camps were located } \\
\text { inside the restricted zone. }\end{array}$ \\
\hline Nov. $8^{\text {th }}$ & IV & $\begin{array}{l}\text { Volcanic activity } \\
\text { started to decrease } \\
\text { in intensity. }\end{array}$ & $\begin{array}{l}\text { Most of the IDP camps utilized after the main explosion } \\
\text { were public buildings (schools, hospitals, stadiums, village } \\
\text { halls, and universities) or even residents' houses or yards. }\end{array}$ & $\begin{array}{l}\text { Local authorities faced logistical } \\
\text { difficulties (e.g. recording IDPs, } \\
\text { distributing aid and assistance). }\end{array}$ \\
\hline Nov. $13^{\text {th }}$ & IV & $\begin{array}{l}\text { Decrease in the } \\
\text { explosive activity } \\
\text { of the volcano. }\end{array}$ & & 381,696 IDPSs. \\
\hline \multicolumn{5}{|c|}{ 5. Decreased volcanic activity (14-19 November 2010) } \\
\hline Nov. $14^{\text {th }}$ & $\begin{array}{c}\text { IV } \\
20 \mathrm{~km}-15 \mathrm{~km}-10 \mathrm{~km}\end{array}$ & $\begin{array}{l}\text { Decrease of the } \\
\text { explosive activity } \\
\text { of the volcano. }\end{array}$ & $\begin{array}{l}\text { CVGHM: recommended decreasing the radius of the danger } \\
\text { zone as follows: maintaining a radius of } 20 \mathrm{~km} \text { for the sector } \\
\text { between the Boyong and Gendol rivers (mainly within } \\
\text { Sleman District), but reducing the radius to } 15 \mathrm{~km} \text { for } \\
\text { Magelang District and to } 10 \mathrm{~km} \text { for Klaten and Boyolali }\end{array}$ & $\begin{array}{l}399,403 \text { IDPSs, reaching a peak } \\
\text { level. } \\
464,328 \text { habitants in the } \\
\text { restricted area. }\end{array}$ \\
\hline
\end{tabular}




\begin{tabular}{|c|c|c|c|c|}
\hline \multirow[b]{2}{*}{ Nov. $19^{\text {th }}$} & \multirow[b]{2}{*}{ IV } & & \multirow[t]{2}{*}{ Districts. } & \multirow[b]{2}{*}{$\begin{array}{l}\text { 272,124 IDPSs. } \\
\text { - Many IDPSs were closed } \\
\text { - Concentration in one central } \\
\text { camp in Maguwoharjo. }\end{array}$} \\
\hline & & & & \\
\hline \multicolumn{5}{|c|}{ 6. Post-eruption stage (20 November-9 December 2010) } \\
\hline Nov. $20^{\text {th }}$ & $\begin{array}{c}\text { IV }-15 \mathrm{~km}-10 \mathrm{~km}-5 \\
\mathrm{~km}\end{array}$ & $\begin{array}{l}\text { Decrease of the } \\
\text { explosive activity } \\
\text { of the volcano. }\end{array}$ & $\begin{array}{l}\text { CVGHM: recommended decreasing the radius of the danger } \\
\text { zone as follows: } 15 \mathrm{~km} \text { for the sector between Boyong and } \\
\text { Gendol rivers, } 10 \mathrm{~km} \text { for the rest of Sleman District, } \\
\text { Magelang and Klaten Districts, and } 5 \mathrm{~km} \text { for Boyolali } \\
\text { District. }\end{array}$ & $\begin{array}{l}190,902 \text { habitants in the } \\
\text { restricted area. }\end{array}$ \\
\hline Dec. $3^{\text {rd }}$ & III-10 km & & & 51,924 IDPSs. \\
\hline Dec. $9^{\text {th }}$ & III-10 km & & & $<20,000$ IDPSs. \\
\hline
\end{tabular}

* Four warning levels, from I to IV, define volcanic activity as follows: "normally active, on guard, prepared, and beware conditions".

** Internally Displaced Persons.

*** Center for Volcanology and Geological Hazard Mitigation.

**** Merapi Volcano Observatory.

****** Pyroclastic Density Currents

Key: The 2010 Mt. Merapi eruption can be divided into six chronological stages. The explosive activity of the volcano has led to a wide range of actions and recommendations starting from September $20^{\text {th }}$ to December $9^{\text {th }} 2010$. On November $5^{\text {th }} 2010$, sustained eruptions occurred, exerting a death toll to nearly 200 people. This stage was characterized by an absence of coordination between CVGHM and other emergency planners. Besides, the number of displaced people increased dramatically over time and reached its peak on November $14^{\text {th }}$ with 399,403 IDPSs.

Table 5. The most recurrent "References", "Verbs" and "Adjectives" in the themes "Early warning and risk monitoring", as generated by Tropes. Numbers in brackets indicate the number of occurrences.

\begin{tabular}{|l|l|}
\hline References & - Crises: Lahar (60), River (25), Calamity (22), Alarm (20), Volcano (19). \\
& - Dates: 2010 (10), 2011 (9). \\
& - Locations: Village (17), Merapi (14), Area (10). \\
& - Communication \& Medias: Information (14), Guard (8), Instruction (4). \\
& - Social Groups: People (12), Leader (11), Refugee (7) and Inhabitant (5). \\
\hline Verbs & - Verbs of state: to Be (50), to Know (5), to Happen (4). \\
& - Verbs of action: to Face (18), to Evacuate (8), to Announce (6). \\
\hline Adjectives & - Local (7), Warning (5), Dangerous (4), Public (4), Urgent (5). \\
\hline
\end{tabular}

Key: The table reflects the dangerous context in which communities operate, although they are aware of the risk of volcanic eruption. One respondent stated: "People live very close to the lahar. With limited funds, people do not want to move from there". The early warning system around Mt. Merapi is based on the analysis of instrumental and visual observations.

Table 6. The most recurrent "References", "Verbs" and "Adjectives" in the themes "Improvement projects", as generated by Tropes. Numbers in brackets indicate the number of occurrences.

\begin{tabular}{|l|l|}
\hline References & - Locations: Villages (36), District (5), Location (3). \\
& - Crisis: Calamity (9), Victim (8), Emergency (4), Risk (3). \\
& - Health, Life \& Casualties: House (16), Health (3). \\
& - Business \& Industry: Benefit (10), Cost (5), Economy (3), Electricity (3). \\
\hline
\end{tabular}




\begin{tabular}{|l|l|}
\hline Verbs & $\begin{array}{l}\text { - Verbs of state: to Be (47), to Have (11). } \\
\text { - Verbs of action: to Build (5), to Support (5). }\end{array}$ \\
\hline Adjectives & - Temporary (19), Public (6), Local (3), Urgent (3). \\
\hline
\end{tabular}

Key: Local inhabitants consider project impact as positive because they feel safer and more motivated to work during their temporary stay in shelters. Our respondents underline the improvement of the economic and sanitation conditions (electricity, water).

Table 7. Three categories of institutions are acting around Mt. Merapi. Numbers in brackets indicate the number of occurrences.

\begin{tabular}{|l|l|}
\hline Institutions & Examples \\
\hline 1. Local Governments (LG) & $\begin{array}{l}\text { District and Sub-District, Municipality, Village, } \\
\text { Police and army, Department of public works, } \\
\text { Department of health. }\end{array}$ \\
\hline 2. Civil Society Organizations (CSO) & Rescue team, Private companies. \\
\hline 3. Community Representatives (CR) & Village chief. \\
\hline
\end{tabular}

Key: There is a strong coordination among institutions in Mt. Merapi with a growing involvement of NGOs and private organizations.

Table 8. Means and localities used for the dissemination of information, as generated by Tropes software. Numbers in brackets indicate the number of occurrences.

\begin{tabular}{|l|l|}
\hline Dissemination of information & Examples \\
\hline Means & $\begin{array}{l}\text { Public meetings (17), Radio (15), Television (14), Evacuation } \\
\text { simulation (13), Press (12), Posters (11). }\end{array}$ \\
\hline Localities & $\begin{array}{l}\text { Public places (15), Mosques (12), Schools, Work places, } \\
\text { Police stations (12), Houses (11), Health centers (9) and } \\
\text { Associations (sport, politics) (5). }\end{array}$ \\
\hline
\end{tabular}

Key: A wide range of communication supports is used to inform people in all relevant places where they spend time (e.g. home, schools, public administrations, worship spaces). 
Table 9. The assessment framework of the adaptive capacity around Mt. Merapi volcano.

\begin{tabular}{|c|c|c|}
\hline Key parameters & $\begin{array}{l}\text { Facilitating factors to an adaptive } \\
\text { capacity of Mt. Merapi system }\end{array}$ & $\begin{array}{l}\text { Limiting factors to an adaptive capacity } \\
\text { of Mt. Merapi system }\end{array}$ \\
\hline $\begin{array}{l}\text { 1. System } \\
\text { description }\end{array}$ & $\begin{array}{l}\text { - Well-defined system. } \\
\text { - Perception of volcanic eruption as a } \\
\text { potential risk. }\end{array}$ & $\begin{array}{l}\text { Complex interactions across institutions } \\
\text { of different scales (e.g. local institutions). } \\
\text { Eruptions and lahars pose complex, } \\
\text { uncertain and ambiguous risks. }\end{array}$ \\
\hline 2. Techn & $\begin{array}{l}\text { - Monitoring and warning systems exist } \\
\text { in all rivers that drain the Merapi } \\
\text { volcano. } \\
\text { - Mapping using GPS. } \\
\text { - Community awareness of "disaster } \\
\text { management" devices/technology. }\end{array}$ & $\begin{array}{l}\text { Electric shortage. } \\
\text { Seismograph out of order. } \\
\text { Lack of advanced technology. } \\
\text { Many early warning devices were stolen } \\
\text { and/or vandalized. }\end{array}$ \\
\hline 3. Infr & $\begin{array}{l}\text { - Infrastructural projects have been } \\
\text { conducted (e.g. build temporary } \\
\text { shelters, provide clean water and } \\
\text { determine evacuation routes). }\end{array}$ & $\begin{array}{l}\text { - Lack of adequate infrastructure (e.g. } \\
\text { dams, bridges, soil protection, roads, } \\
\text { river excavators, public bathing, } \\
\text { shelters). }\end{array}$ \\
\hline 4. Ins & $\begin{array}{l}\text { - Presence of International institutions } \\
\text { (e.g. Indonesian Red Cross). } \\
\text { - Coordination among institutions } \\
\text { especially when disasters occur. } \\
\text { - CSO provide quick support to local } \\
\text { inhabitants. } \\
\text { - Coordination among institutions for } \\
\text { the dissemination of information. } \\
\text { - Training of disaster management units } \\
\text { (national and local levels). } \\
\text { - Social networks among the } \\
\text { population. } \\
\text { - Community-based disaster and crisis } \\
\text { management }\end{array}$ & $\begin{array}{l}\text { - Presence of bureaucracy in LG. } \\
\text { - Lack of respect for law enforcement. } \\
\text { - Limitation of CSO to projects and short- } \\
\text { term activities. } \\
\text { - Coordination efforts among institutions } \\
\text { are only oriented towards relief } \\
\text { (emergency management). } \\
\text { - Time wasting in coordinating different } \\
\text { institutions. } \\
\text { - Absence of continuous contact between } \\
\text { institutions. } \\
\text { - Population relies on informal local } \\
\text { networks (neighbors) for rescue. }\end{array}$ \\
\hline $\begin{array}{l}\text { 5. Information and } \\
\text { skills }\end{array}$ & $\begin{array}{l}\text { - Information dissemination with a } \\
\text { variety of means and localities. } \\
\text { - Preparation of evacuation maps and } \\
\text { emergency simulations. } \\
\text { - Education for disaster management. }\end{array}$ & $\begin{array}{l}\text { Lack of public awareness in reacting to } \\
\text { emergency simulations. } \\
\text { Unprecise quantitative documentation. } \\
\text { Emergency plan depends to a large } \\
\text { extent on CSO and CR. }\end{array}$ \\
\hline $\begin{array}{l}\text { 6. Economic and } \\
\text { financial } \\
\text { resources }\end{array}$ & $\begin{array}{l}\text { - Financial compensation provided by a } \\
\text { wide range of institutions (including } \\
\text { social capital/local community } \\
\text { funds/reserves in case of disaster). } \\
\text { - Financial compensation can take } \\
\text { different forms such as food, clothes. }\end{array}$ & $\begin{array}{l}\text { - Time wasting in delivering the } \\
\text { compensation. } \\
\text { - Dependence on funds from external } \\
\text { parties. } \\
\text { - Absence of sophisticated financial } \\
\text { coverage such as catastrophe bonds. } \\
\text { - Limited commercial, industrial and } \\
\text { agricultural activities. }\end{array}$ \\
\hline
\end{tabular}

Key: This table evaluates the adaptive capacity around Mt. Merapi. Although a number of actions (e.g. evacuation simulations, coordination efforts between institutions) have been undertaken, a number of limitations persist (e.g. lack of facilities, poor infrastructure). 
Figure captions

Figure 1. Location, setting of Merapi volcano in central Java and hazard-zone map [29]. A.

Location of Merapi volcano, the southernmost and youngest volcano of a $165^{\circ}$-trending range of composite cones comprising, from N to S: Ungaran, Telomojo, Merbabu and Merapi volcanoes and surrounding cities. B. SPOT-5 image of the Merapi-Merbabu area from 10 june 2011, looking NW and draped on an SRTM-DEM. Merapi hazard zones (KRB I-III), as redefined after the 2010 eruption and comprising first, second and third hazard zones are outlined.

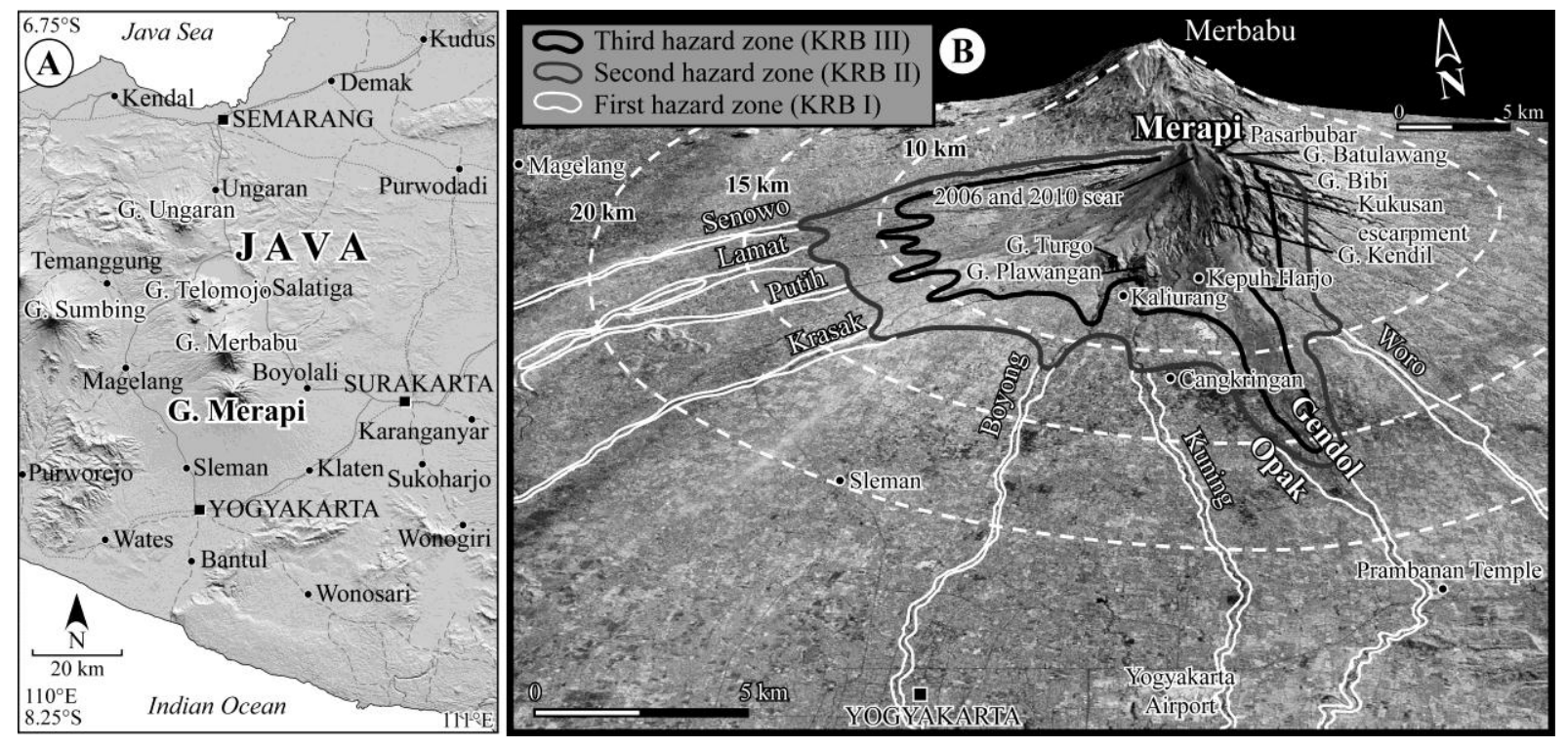

Figure 2. Connections between the reference "Catastrophe" and other references. Our data set was processed using Tropes.

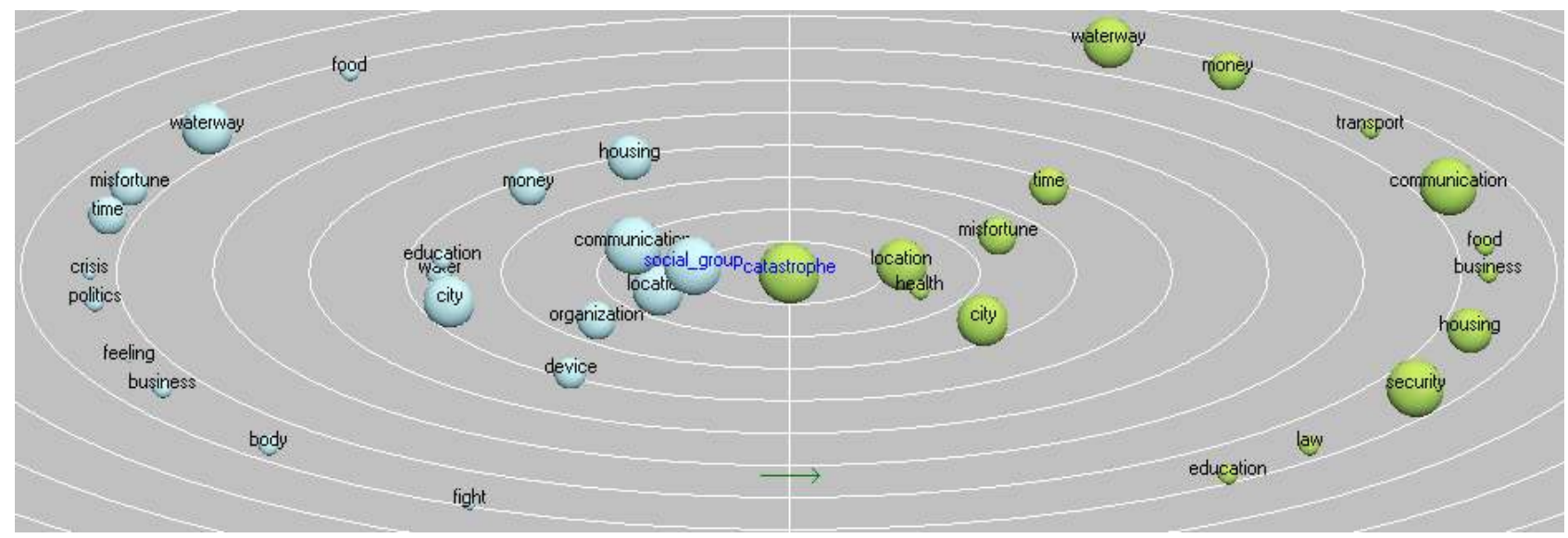


Figure 3. Flow diagram of the administrative levels and the communication chains in the area of Mt. Merapi.

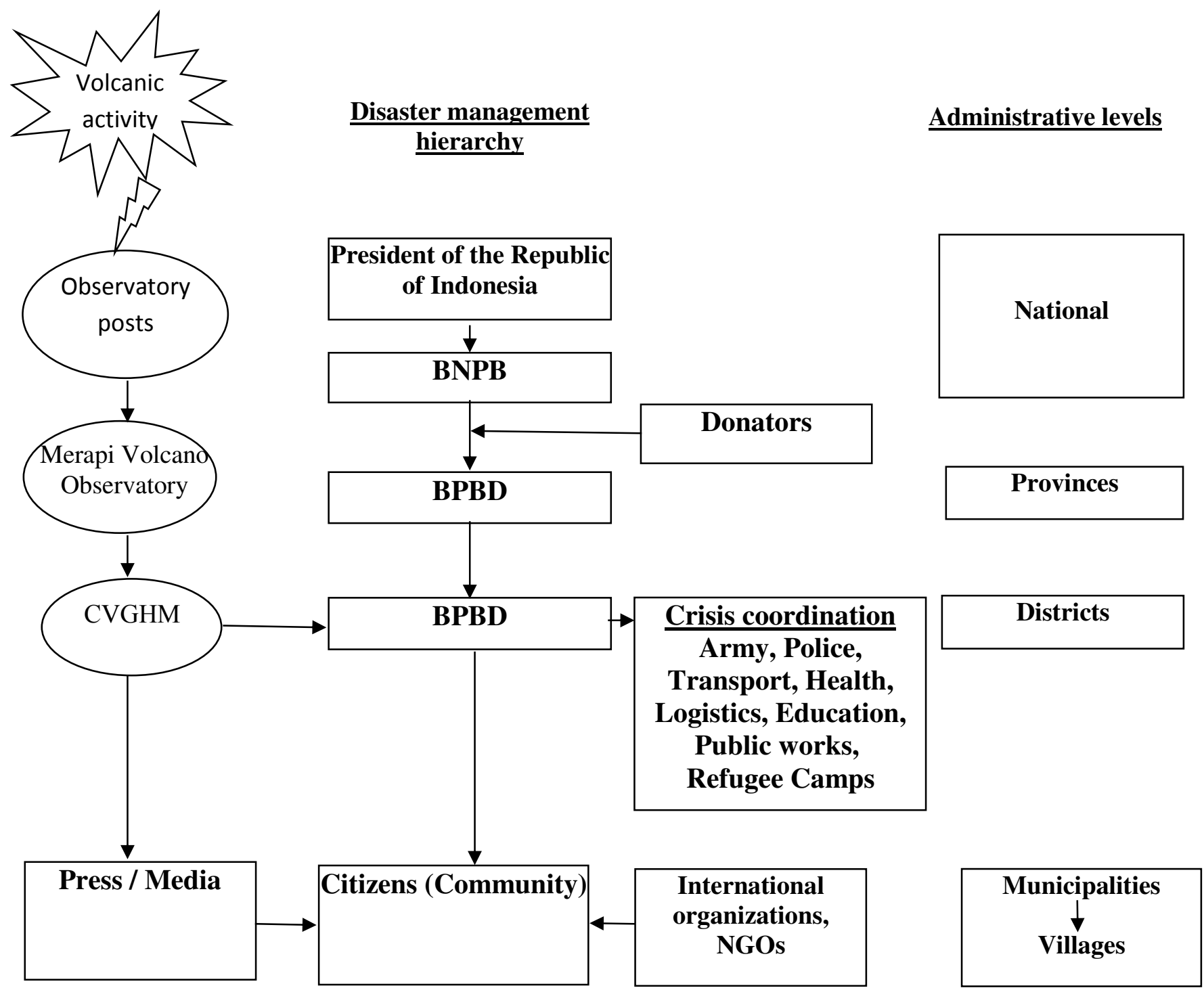

Abbreviations and acronyms:

BNPB: Badan Nasional Penanggulangan Bencana (National Disaster Management Agency). BPBD: Badan Penanggulangan Bencana Daerah (Regional Disaster Management Agency).

CVGHM: Center for Volcanology and Geological Hazard Mitigation. 
Figure 4. Various aspects of our fieldwork after the eruption of Mt Merapi (pictures: G. Enjolras).

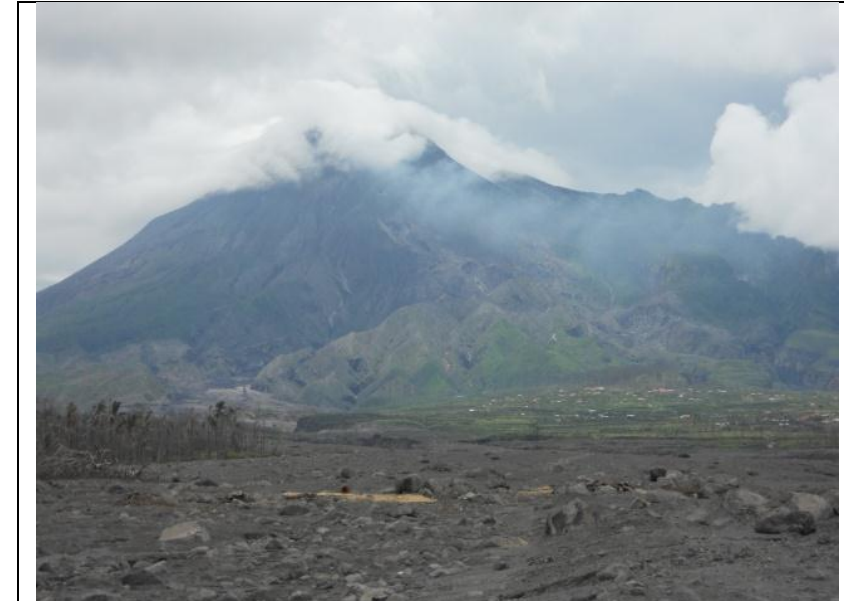

The slopes of Mt Merapi in February 2011. At the foreground, destructions by pyroclastic surges and lahars. At the background, remaining inhabitants (here: Gendol River).

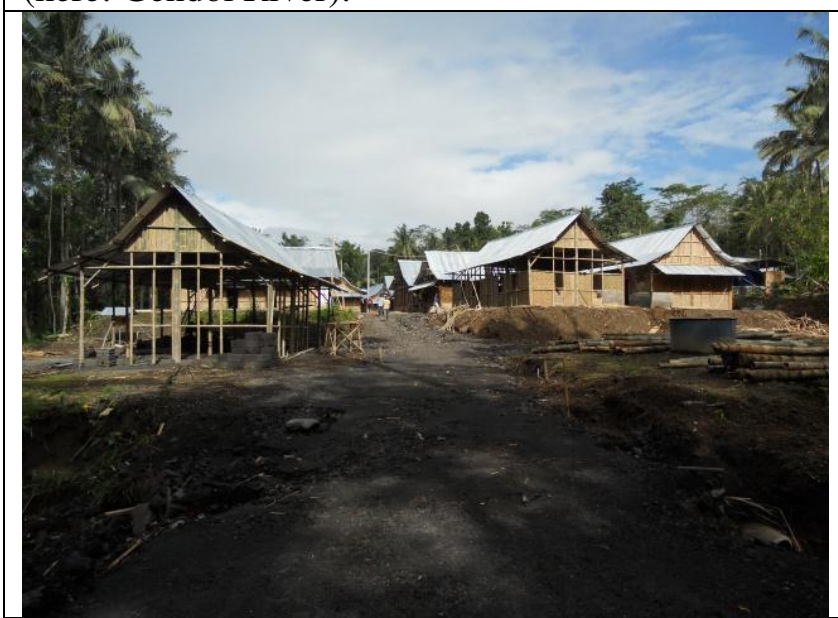

People who lost their home were given the opportunity to live in shelters established close to their ancient village but outside river channels (here: Cangkringan village).

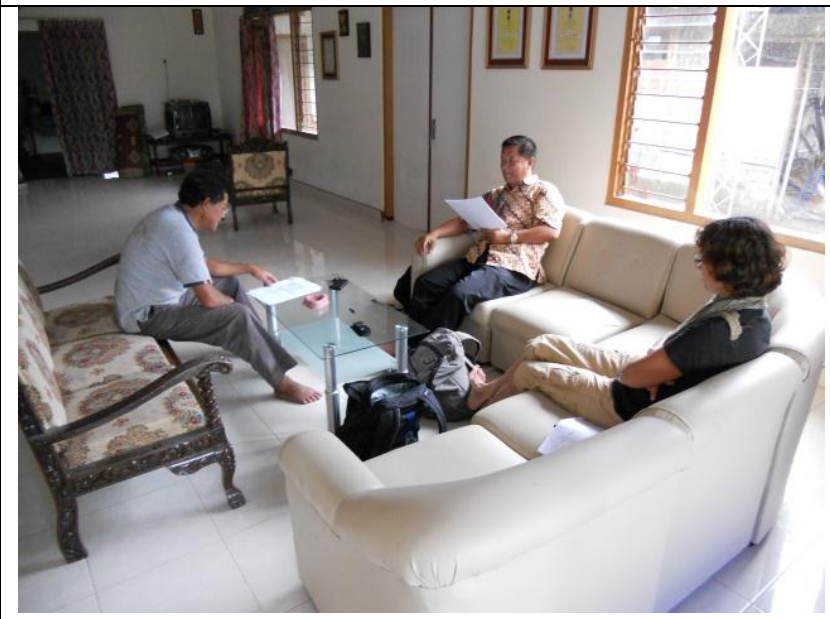

An example of survey performed within risk management institutions (here: SIBAT, Kaliurang village).

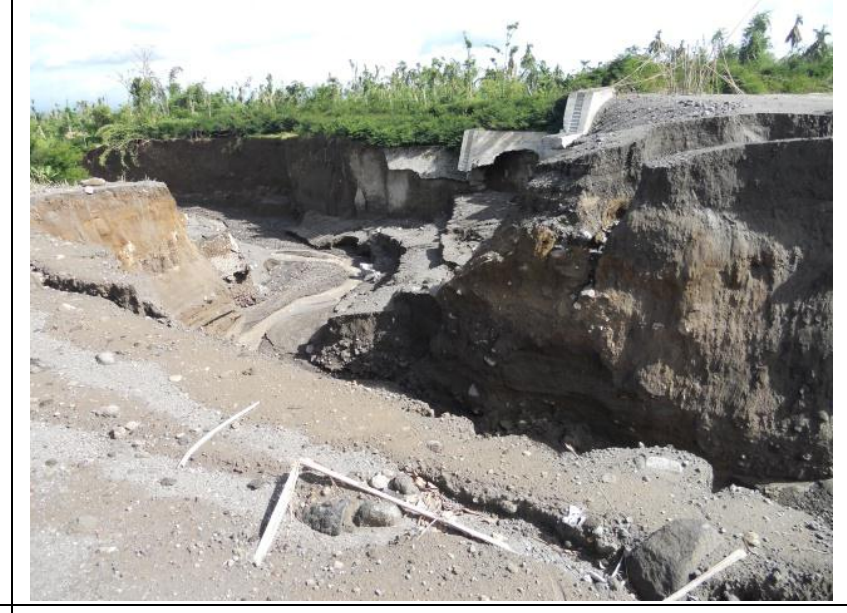

An example of broken dam on the slopes of Mt Merapi. Many facilities against floods and lahars were destroyed following the eruption (here: Woro River).

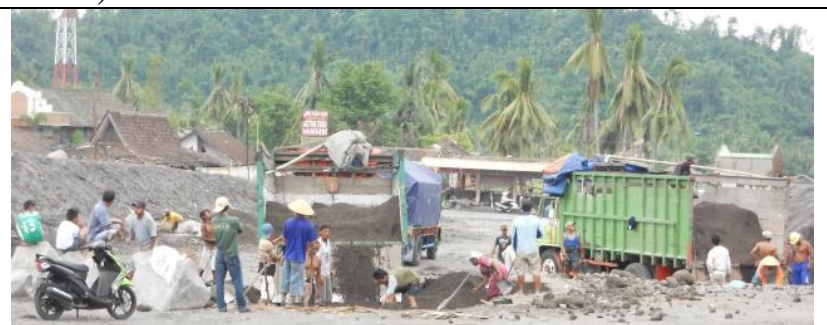

The volcano is a source of benefits for many people who extract building material from flooded valleys (here: Magelang village).

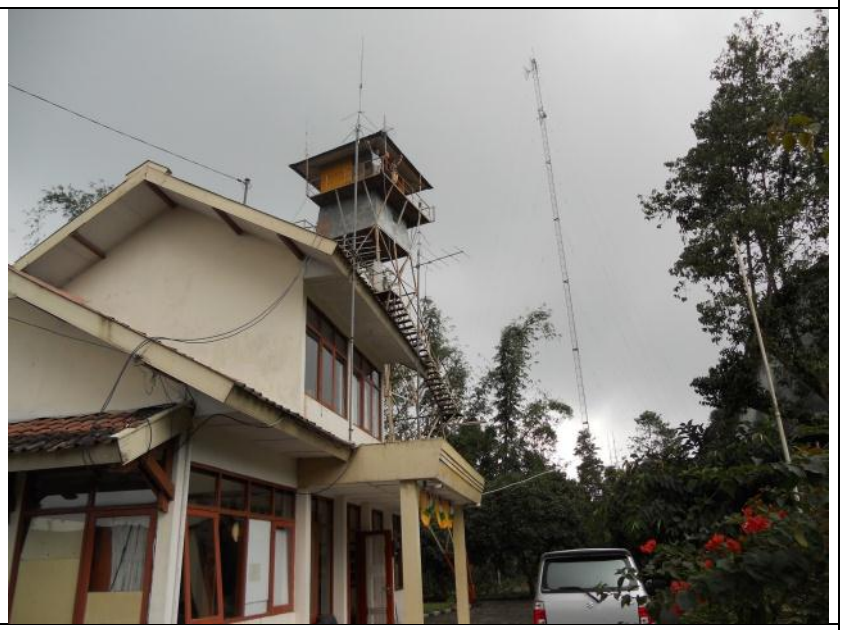

The eruption emphasized the key role of observatories in risk prevention (here: Kaliurang). 
Appendix 1: Questionnaire used for the surveys

\section{Semi-structured interview / Questionnaire on lahar risk management}

Identification of the respondent

\begin{tabular}{|l|l|}
\hline Name / Surname & \\
\hline Age & \\
\hline Sex & \\
\hline Adress & \\
\hline Telephone & \\
\hline Email & \\
\hline Institution & $\begin{array}{l}\text { Primary School } \\
\text { Task }\end{array}$ \\
\hline Years of incumbent & $\begin{array}{l}\text { Senior High School } \\
\text { University } \\
\text { Education }\end{array}$ \\
\hline
\end{tabular}

Within the framework of this survey, we are interested in the risks and we are particularly focusing on natural risks, that is to say the risks relative to our environment

Q1. Order these hazards related to our environment from the most important to the least important (From 1 to $5,1=$ most important; $5=$ less important)

... Volcanic eruption

... Lahar or mud flow

... Seismic risk

... Tsunami

... Other

With respect to the risks of lahars, to which the region is exposed 
Q2. Are you aware of lahar risk on Merapi volcano?

a Yes

a No

Q3. Have you already witnessed a lahar directly?

a Yes

a No

If your answer is positive, did you observe a change in your professional behavior?

Q4. How often have you faced risky situation generated by lahars?

Q5. On this scale, please indicate the risk level a lahar represents for the population (life, house, job...)? $(0=$ no threat; $10=$ great threat).

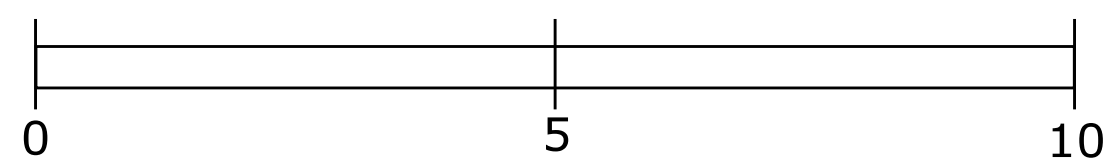

Q6. On this scale, please indicate the probability of occurrence of a destructive lahar in the next two years.

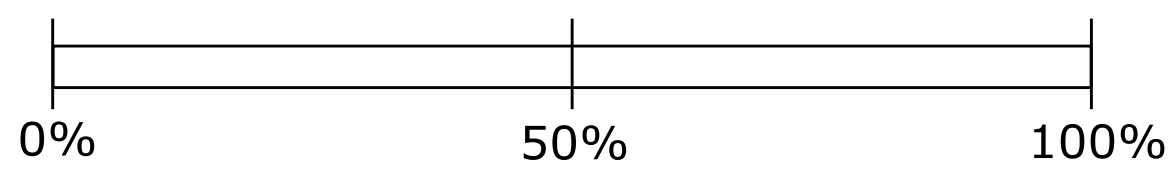

Q7. On this scale, please indicate the probability of occurrence of a destructive lahar in the next five years.

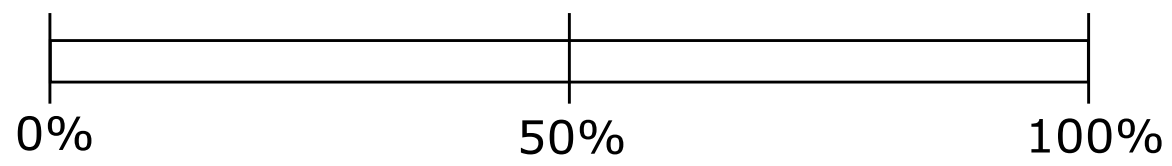


Regarding the management of lahar risks...

Q8. If a lahar is coming, which institution should first react? (Please choose a single answer)

a The neighbors

- The local authorities (Rt, Rw, village chief, rescue team, personalities)

a The sub-district authorities

a The regency

口 PBPPTK

Q9. According to you, which decisions should be taken in order to mitigate risks and to reduce the loss (human and material) generated by lahars?

Q9a. Administrative solutions

\begin{tabular}{|l|l|l|l|}
\cline { 2 - 4 } \multicolumn{1}{c|}{} & Little & Much & Not at all \\
\hline Signs in dangerous areas & & & \\
\hline (More) precise zoning of risky areas & & & \\
\hline $\begin{array}{l}\text { Preserved zone near the volcano (no construction, } \\
\text { natural park) }\end{array}$ & & & \\
\hline $\begin{array}{l}\text { Legislation that prevent the population continuing } \\
\text { building and living along the rivers }\end{array}$ & & & \\
\hline $\begin{array}{l}\text { National legislation for the education and the } \\
\text { protection of the population }\end{array}$ & & & \\
\hline Other & & & \\
\hline
\end{tabular}

Q9b. Technical solutions

\begin{tabular}{|l|l|l|l|}
\cline { 3 - 4 } \multicolumn{1}{c|}{} & Little & Much & Not at all \\
\hline Evacuation roads & & & \\
\hline Retaining walls & & & \\
\hline Dams (sabo...) & & & \\
\hline Floodway & & & \\
\hline Other & & & \\
\hline
\end{tabular}

Q9c. Humanitarian solutions

\begin{tabular}{|l|l|l|l|}
\cline { 2 - 4 } \multicolumn{1}{c|}{} & Little & Much & Not at all \\
\hline Compulsory purchase & & & \\
\hline Emergency evacuation & & & \\
\hline Population transfer & & & \\
\hline Other & & & \\
\hline
\end{tabular}


Q9d. Preventive solutions

\begin{tabular}{|l|l|l|l|}
\cline { 2 - 4 } \multicolumn{1}{c|}{} & Little & Much & Not at all \\
\hline Educative projects (population, students, teachers) & & & \\
\hline Evacuation simulation & & & \\
\hline Mass media information & & & \\
\hline Other & & & \\
\hline
\end{tabular}

Q9e. Financial solutions

\begin{tabular}{|l|l|l|l|}
\cline { 2 - 4 } \multicolumn{1}{c|}{} & Little & Much & Not at all \\
\hline Individual savings & & & \\
\hline Solidarity fund & & & \\
\hline Compensation of loss by the regency & & & \\
\hline Intervention of the Indonesian State & & & \\
\hline International help and support & & & \\
\hline Other & & & \\
\hline
\end{tabular}

Q10. Do you have indicators that allow to measure and to evaluate the effectiveness of the policies against catastrophes?

व Yes

a No

If your answer is positive, can you describe them?

\section{If a disaster occurs (volcanic or lahar crisis)}

Q11. Does a monitoring and warning system exist on all rivers that come from Merapi volcano?

a Yes

a No

Q12. Who gives the alert? Is it frequent? 
a Yes

a No

Related to the risk management in case of lahars

Q14. Can you describe next the stages of this plan and how it would be carried out in case of emergency? (From the implementation of the plan to the protection of the population) How is it implemented in terms of spatial organization, priorities?

Q15. Do you have an idea of the human loss than a lahar can cause depending of its intensity?

口 Yes

a No

If your answer is positive, do you have in mind a recent example?

Q16. Do you have an idea of the material loss than a lahar can cause depending of its intensity?

口 Yes

a No

If your answer is positive, do you have in mind a recent example?

Q17. Which institutions can provide a material help?

口 Local institutions (villages, Rt, Rw)

\ The sub-regency

a The regency

a The province 

\ The central government
口 International institutions
口 Private companies
口 Others

Q18. Which form can take the financial help?
口 Solidarity funds
口 Individual insurance policies
- Reserve funds devoted to cases of emergency
๑ Donations

a Others

Q19. How does the financial compensation work (from the national level to the victims)?

Q20. How could the financial responses to lahar damages be improved?

With respect to the prevention and to decisions to prevent and reduce the risks:

Q21. Are you informed on the safety measures that are to follow in case of a lahar?
a Yes
a No

Q22. Which means are currently used to disseminate information on lahar risks?

Q22a. How the information is provided? 


\begin{tabular}{|l|r|r|l|}
\cline { 2 - 4 } \multicolumn{1}{c|}{} & Yes & No & $\begin{array}{c}\text { If your answer is positive, please mention the } \\
\text { frequency of use }\end{array}$ \\
\hline Pamphlets & & & \\
\hline Posters & & & \\
\hline Evacuation simulation & & & \\
\hline Public meetings & & & \\
\hline Radio & & & \\
\hline Television & & & \\
\hline Press & & & \\
\hline Others & & & \\
\hline
\end{tabular}

Q22b. Where the information is provided?

\begin{tabular}{|l|l|l|l|}
\cline { 2 - 4 } \multicolumn{1}{c|}{} & \multicolumn{1}{c|}{ Oui } & Non & Si oui, fréquence \\
\hline In schools & & & \\
\hline In public places & & & \\
\hline In work places & & & \\
\hline In health centers & & & \\
\hline In mosques & & & \\
\hline In police stations & & & \\
\hline At home & & & \\
\hline Associations (sport, politics) & & & \\
\hline Others & & & \\
\hline
\end{tabular}

Q22c. When the information is provided to the following people?

\begin{tabular}{|l|l|l|}
\cline { 2 - 3 } \multicolumn{1}{c|}{} & \multicolumn{1}{c|}{ Date } & Frequency \\
\hline $\begin{array}{l}\text { Population in vulnerable or isolated } \\
\text { areas }\end{array}$ & & \\
\hline Whole population & & \\
\hline Children, Students & & \\
\hline Health workforce & & \\
\hline Army and Police & & \\
\hline Local authorities & & \\
\hline Others & & \\
\hline
\end{tabular}


Q23. What are the implications of the local population beliefs on the diffusion and the assimilation of the information?

Q24. If you had financial and technical means, what would you propose to reduce lahar risk and its consequences?

In this section, we will discuss of lahar risk management and decision taking.

Q25. With which institutions are you working with in order to get information on lahar risks? 
Q26. Could you mention the relationships you have with these institutions that manage risk? Which one is the most important for you? Why?

Q27. Do you think that the relationships between the different institutions in charge of the risk are coherent? Why? What is the position of these institutions regarding risk management?

Q28. Among the projects you are involved in so far, which are the main obstacles that you have identified?

Q29. Among the different projects you are involved in, which are the best results that you have obtained? Can you rank them starting from the most important? 


\section{Project}

Which solutions have been implemented to face the risks produced by the lahars? Have they been efficient?

\section{Q1. Projects}

\begin{tabular}{|l|l|}
\hline Name of the project(s) & \\
\hline What are the objectives? (Zoning, risks reduction...) & \\
\hline Financing: Who? How? Beginning? Cost? & \\
\hline $\begin{array}{l}\text { What are the (highest-priority) challenges? } \\
\text { (Agricultural, commercial and industrial activities, } \\
\text { houses, public infrastructure, facilities, networks, } \\
\text { environment...) }\end{array}$ & \\
\hline $\begin{array}{l}\text { Which physical and monetary indicators are used to } \\
\text { measure the effective impact of the project(s)? }\end{array}$ & \\
\hline
\end{tabular}

\section{Q2. Preparation and planning}

Can you describe the location of the equipped areas?

Which type of preparation has been carried out?

Do the project(s) have an impact on the creation or the modification of planning schemes?

\section{Q3. Population and stakeholders}

Can the population receive support in case of crisis?

What are the stakeholders' participation on the project(s)?

Are they motivated by the project(s)?

\section{Q4. Purpose}

Evaluation of the impacts, the damages and the expected benefits of the project(s)? +/-

At the moment (or at the end of the project), to what type of crisis are you able to face? 